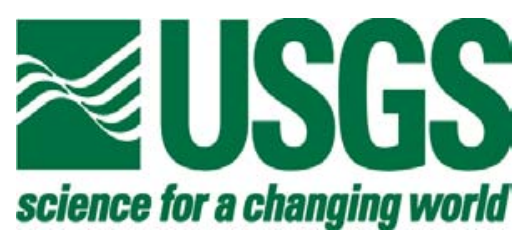

\title{
Evaluating the Impacts of White-tailed Deer (Odocoileus virginianus) on Vegetation within Pea Ridge National Military Park
}

\author{
April 2005
}

By:

Keith W. Grabner ${ }^{1}$

Matthew Struckhoff ${ }^{1}$

Deborah A. Buhl ${ }^{2}$

U.S. Geological Survey

Northern Prairie Wildlife Research Center

$871137^{\text {th }}$ Street SW

Jamestown, ND 58401

\footnotetext{
${ }^{1}$ Current Address, Ecologist, USGS - Columbia Environmental Research Center, 4200 New Haven Rd, Columbia, MO 65201. 573-875-5399

${ }^{2}$ Statistician, USGS - Northern Prairie Wildlife Research Center, $871137^{\text {th }}$ Street SW., Jamestown, ND 58401, 701-253-5532
} 


\section{Table of Contents}

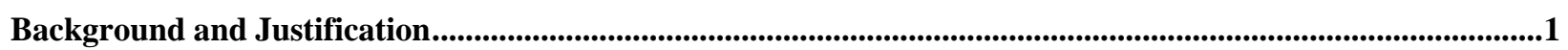

Purpose and Objectives.......................................................................................................................................................

Purpose:

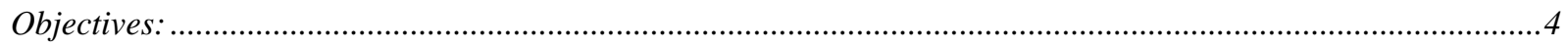

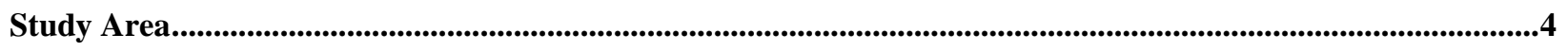

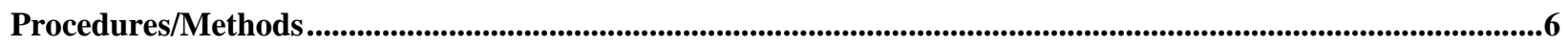

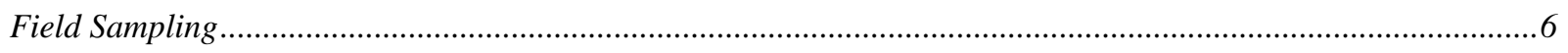

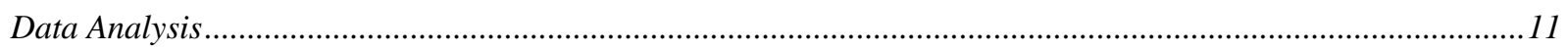

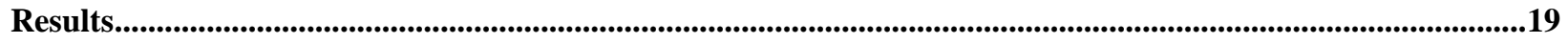

Vegetation Community Analysis ................................................................................................................19

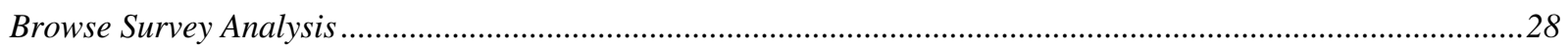

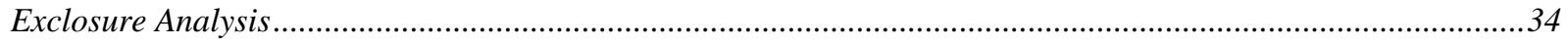

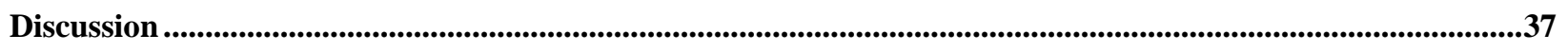

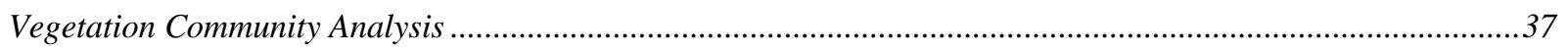

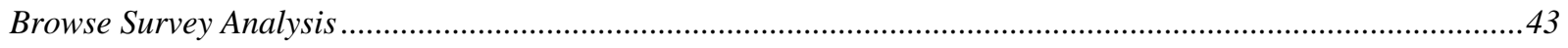

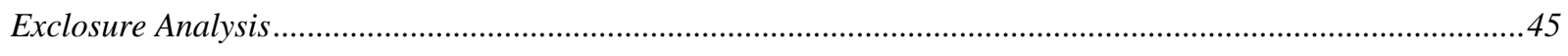

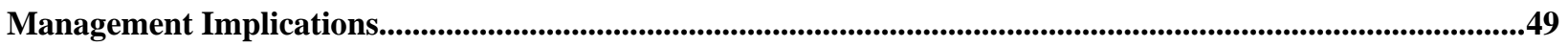

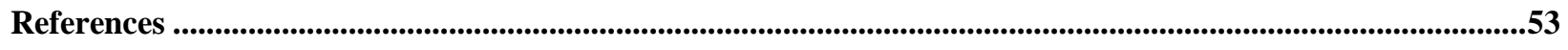




\section{Figures}

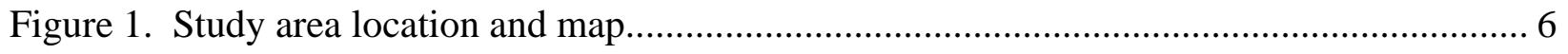

Figure 2. Deer browse and exclosure plot diagram. …….......................................................... 7

Figure 3. Location of deer browse and exclosure plots. ................................................................ 9

\section{Tables}

Table 1. Estimated sample size for adequate number of deer browse plots. .................................. 9

Table 2. Comparison of overstory conditions by vegetation community..................................... 20

Table 3. The five most frequent overstory species in each community......................................... 21

Table 4. Comparison of woody understory vegetation by community with sample years

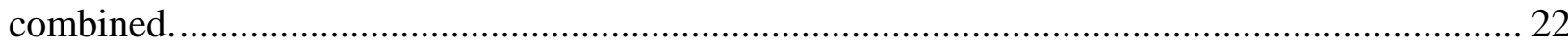

Table 5. Summary of woody understory vegetation by sample year and vegetation community.

Table 6. Understory species with the highest two-year mean densities in each community type.

Table 7. Mean woody understory density by height class and vegetation community, both

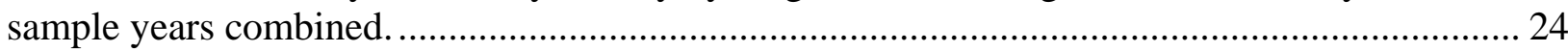

Table 8. Mean woody understory species richness by height class and vegetation community, both sample years combined...................................................................................................... 26

Table 9. Total twigs and total browsed twigs found in each community by year. ....................... 28

Table 10. Proportion of twigs browsed among four vegetation communities and between

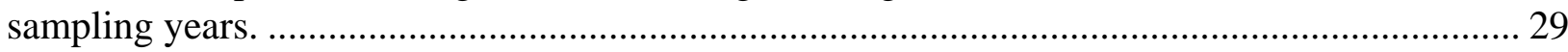

Table 11. Comparison of proportion of twigs browsed between height classes............................ 30

Table 12. List of encountered species within the oak-hickory species group. ............................. 31

Table 13. Comparison of proportion of twigs browsed between oak and hickory seedlings

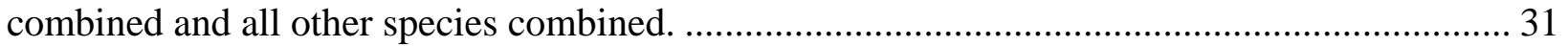

Table 14. Top five preferred and avoided species browsed within each vegetation community. 32 Table 15. Individual species browse intensity by year for species with 50 or more recorded

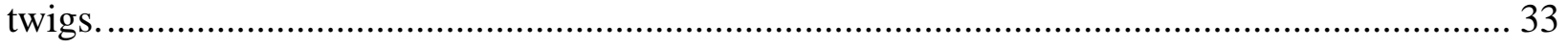

Table 16. Comparison of mean density and height by vegetation community and exclosure

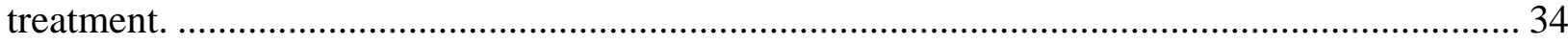




\section{Background and Justification}

Pea Ridge National Military Park (PERI) preserves and commemorates the Battle of Pea Ridge, a major Civil War battle fought in 1862. When the park was created in 1956, the enabling legislation mandated that park managers protect the cultural resources of the park. Implicit in this mandate was the understanding that plant communities should approximate their condition and appearance at the time of the battle.

Park resource managers at PERI are concerned that browsing by white-tailed deer (Odocoileus virginianus) might be adversely affecting plant communities by 1) actively transforming existing communities away from their historical appearance and 2) hindering efforts to restore plant communities to approximate historical conditions. Resource managers at PERI have estimated white-tailed deer densities to be from 40 to 60 deer/square mile, while the Arkansas state average deer density is 10 deer/square mile (Zack Holden, pers. comm. ${ }^{\ddagger}$ ). During preliminary investigations for this study, we observed evidence of possible excessive deer browse in wooded sections of the park, including suppressed oak and hickory regeneration, diminished recruitment of oak and hickory saplings into larger size classes, and a sparse shrub layer.

1) Active transformation of existing communities:

Currently, most of the forested areas of the park maintain an outward appearance similar to that which existed at the time of the battle. However, resource managers are concerned that

\footnotetext{
${ }^{\ddagger}$ Zack Holden, Resource Manager, Pea Ridge National Military Park, December 2001
} 
deer browse may be limiting oak and hickory regeneration, which must be maintained in order to provide new cohorts as forests age (Oliver and Larson 1990). Excessive deer browse has been linked with suppression of tree regeneration (Anderson and Loucks 1979, Marquis 1981, Frelich and Lorimer 1985, Adams and Rieske 2001, Rodewald 2003). Pedersen and Wallis (2004) describe an extreme example of excessive deer browse that could potentially lead to "bottom up" deforestation as mature trees die and regeneration is insufficient to replace them. Other changes that may be less obvious, but equally important, include changes in species composition due to preferential browsing (Marquis 1981, Bowersox et al. 1995, Ritchie et al. 1998, Rooney and Waller 2003).

\section{2) Hindering restoration efforts}

Park resource managers are experimenting with methods of restoring cedar dominated thickets to oak-hickory forest communities. The same mechanisms that could limit tree regeneration in already forested areas would be more problematic in restoration areas. In these areas, establishment of new oak and hickory seedlings may be limited by the absence of seedproducing oaks and hickories and the presence of a dense canopy of non-desirable, invasive species such as cedar. Therefore, there may be limited numbers of desirable seedlings to replace cedar trees. Additionally, new seedlings that germinate after clearing may be at a competitive disadvantage relative to aggressive forbs and carpet-forming woody species that are prevalent in the park and which respond favorably to the opening of cedar thickets, such as Lespedeza cuneata, Rubus spp. and Lonicera japonica. In these areas, preferential browsing by deer on desirable species may be sufficient to prohibit successful recruitment of new cohorts. 
In addition to the effects deer browse may have on tree regeneration, park resource managers are also concerned that deer browse will hinder the efforts to improve the condition of glades, open areas dominated by grasses and drought resistant forbs. The primary concern in glade restoration efforts is that preferential browsing will inhibit the re-establishment of the herbaceous layer; including rare and threatened species often associated with these areas. Preferential deer browsing has been shown to affect rare, threatened and endangered plant populations (Miller et al. 1992, Johnson et al. 1995, Augustine and Jordan 1998) and overall groundflora species composition (Marquis 1981, Ritchie and Tilman 1995, Augustine and Frelich 1998, Frankland and Nelson 2003). These effects may be exacerbated where there are well-established, aggressive forbs such as Lespedeza cuneata, as at Pea Ridge National Military Park.

This study examines both the intensity of deer browsing throughout the PERI, and the park-wide effects of excluding deer from plant communities. We used two methods to accomplish this: 1) browse surveys and 2) deer exclosures. We conducted deer browse surveys in four broadly-defined vegetation community types (old fields, cedar thickets, protected oak forests, and exposed oak forests [definitions in the Procedures/Methods - Field Sampling section]) in order to assess browse intensity. In addition, we constructed deer exclosures and compared the short-term response of vegetation between exclosed and unexclosed areas.

\section{Purpose and Objectives}

\section{Purpose:}

Assess the intensity of deer browsing and the effects of excluding deer browse on woody species and groundflora within Pea Ridge National Military Park. 


\section{Objectives:}

1. Estimate mean stem density and basal area for overstory trees in four vegetation types.

2. Estimate mean stem density, height, and species richness for understory woody vegetation in four vegetation types.

3. Estimate mean groundflora species richness and percent cover in four vegetation types.

4. Quantify differences in the percentage of browsed twigs between four vegetation types.

5. Test if oak and hickory seedlings and saplings are being browsed at a greater intensity than other woody species.

6. Estimate differences in the mean understory stem density, height, and species richness between exclosed and unexclosed areas.

7. Estimate differences in mean groundflora species richness and percent cover between exclosed and unexclosed area.

\section{Study Area}

Pea Ridge National Military Park, located in northwest Arkansas (Figure 1), preserves and commemorates the site of a major 1862 Civil War battle. The vegetation in the 1740 ha. park is comprised of: oak/hickory forests across most of the northern half of the park, hayfields in the south-central and western sections, cedar thickets in the central and southeastern sections, and old fields/woody thickets in the western section of the park (Figure 1).

Park resource managers believe that open fields and forested communities approximate their condition and arrangement at the time of the 1862 battle. At that time, the south-central portion of the park was mostly grazing and hay fields, with scattered small tracts of row crops. These areas have remained open fields since the battle and are actively maintained as hayfields by park resource managers today. After the Battle of Pea Ridge, most of the forested areas in the northern section of the park remained forested.

On the other hand, some areas of the park have changed significantly since the time of the battle. For example, many of the forested areas in the southern half of the park were cleared 
as the local population increased. These were maintained as open fields through various agricultural practices, such as hay production and grazing. Since the creation of the park in 1956, these disturbances have been far less frequent or have been abandoned altogether. Many fields are in various stages of forest succession; some fields are dominated by cedar (Juniperus spp.), while other fields are dominated by deciduous woody stems such as Rubus spp., Ulmus alata, Symphoricarpos orbiculatus, and Prunus spp. (Figure 1).

Less obvious, but important changes have occurred among some of the small glades in the park. Glades are among the most species rich communities in Ozark forests and often harbor rare and endangered plants species. Historically, fire and marginal soils with bedrock at or near the surface had limited the density of woody stems on glades. However, reductions in both fire frequency and intensity (first, due to the increasing population after the battle, and then due to early National Park policy of fire suppression) have allowed woody stems, particularly cedar, to invade. Increased woody stems can contribute to a decline in species richness as forbs compete for diminishing space and light. Efforts are under way to restore these glades by reducing woody stems through the use of prescribed fire. 
Figure 1. Study area location and map.

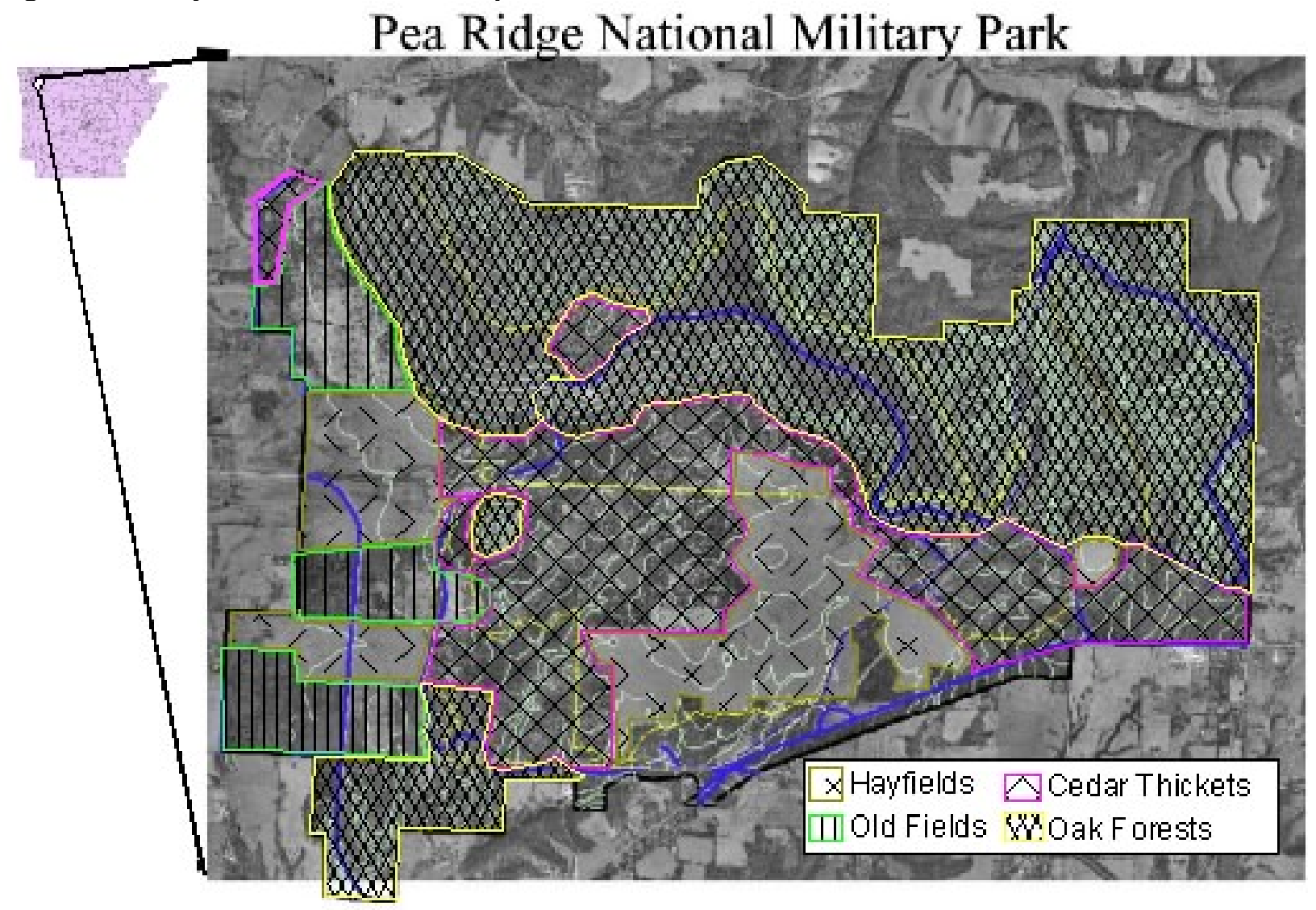

\section{Procedures/Methods}

\section{Field Sampling}

\section{Vegetation Community Characterization (Objectives 1-3)}

We identified four broad vegetation community types within PERI: protected oak/hickory forests $\left(316^{\circ} \leq\right.$ slope aspect $\left.\leq 134^{\circ}\right)$, exposed oak/hickory forests $\left(135^{\circ} \leq\right.$ slope aspect $\leq 315^{\circ}$ ), old fields, and cedar thickets. We randomly located $20 \times 20$ m plots within each community type, using a nested plot design (Figure 2) similar to Strole and Anderson (1992) and Anderson and Loucks (1979). 
Figure 2. Deer browse and exclosure plot diagram.

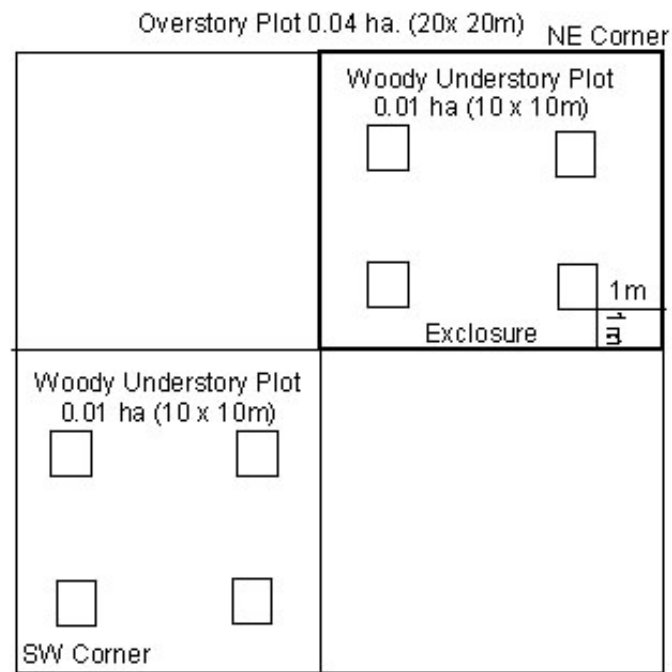

Browse survey plots contained only one woody understory plot.

Exclosures were constructed in the NE corner of the overstory plot.

Exclosed plots also contained paired unexclosed woody understory and groundflora plots in the SW corner.

We permanently marked all plots and recorded their locations using a GPS receiver. The northeast and southwest corners of each plot were marked with a $0.8 \mathrm{~m}$ long metal rod driven at least $0.3 \mathrm{~m}$ into the ground. A metal tag was attached to each rod identifying the plot number and corner (NE or SW). Two witness trees were selected for each corner marker. We identified witness trees to species, measured the diameter at breast height (dbh), and recorded the distance and bearing from the tree to the plot corner. Witness trees were marked with an oval metal tag inscribed with the plot number and corner. We photographed each plot from the northeast corner to provide a visual record of plot appearance prior to initial sampling.

Within each 20 m x 20 m plot, we identified all stems with a diameter at breast height (dbh) greater than $5 \mathrm{~cm}$ to species and measured dbh. These measurements were taken only during the first year. A $10 \times 10 \mathrm{~m}\left(100 \mathrm{~m}^{2}\right)$ understory subplot was located in either the northeast or southwest corner of the overstory plot. We identified woody understory plants (dbh $\leq 5.0 \mathrm{~cm}$ ) to species and measured the height of all woody understory stems between $0.152 \mathrm{~m}$ 
and $2.1 \mathrm{~m}$. The lower limit $(0.152 \mathrm{~m})$ was chosen to save time, given the high density of stems shorter than this height. The upper limit (2.1 m) approximates the maximum height of deer browse (Beals et al. 1960). Stems greater than $2.1 \mathrm{~m}$ were recorded as greater than $2.1 \mathrm{~m}$. We sampled groundflora (all vegetation less than $1 \mathrm{~m}$ tall) within four $1 \mathrm{~m} \times 1 \mathrm{~m}\left(1 \mathrm{~m}^{2}\right)$ quadrats inset 1 meter from the subplot edges (Figure 2). We identified groundflora to species and estimated percent cover. We sampled both understory and groundflora strata in 2002 and in 2003.

In the old field/woody shrub dominated thicket community, we modified the plot design in order to compensate for extremely high stem and twig densities and our short sampling time. We reduced the sampling area of the understory to a $5 \mathrm{~m} \mathrm{x} 5 \mathrm{~m}\left(25 \mathrm{~m}^{2}\right)$ subplot located in the northeast corner of the subplot. Groundflora and overstory sampling was not modified in these communities, and followed the procedures described above.

In the first year, we initially sampled ten plots in each community type. Using calculations of the mean and standard deviations of understory stem density and groundflora species richness, we determined the number (if any) of additional plots needed to detect a 30\% change in these measures with 90\% confidence (Snedecor and Cochran 1989, Table 1). In all communities except old fields (due to logistic constraints and the fact old fields are not a focus of management activities), the required additional plots were established and surveyed within the first year. All plots (i.e., initial plots and additional plots added) were resurveyed the second year. Plot locations are shown in Figure 3. 
Table 1. Estimated sample size for adequate number of deer browse plots.

\begin{tabular}{|c|c|c|c|c|}
\hline \multirow[t]{2}{*}{ Community } & \multicolumn{2}{|c|}{ Stem Density Descriptive Statistics } & \multirow{2}{*}{$\begin{array}{c}\text { Calculated } \\
\text { Sample Size* }\end{array}$} & \multirow{2}{*}{$\begin{array}{c}\text { Number of } \\
\text { Plots }\end{array}$} \\
\hline & Mean & Standard Deviation & & \\
\hline Old Fields & 112.5 & 68.38 & 11.1 & 10 \\
\hline Cedar Thickets & 107 & 57.92 & 8.8 & 10 \\
\hline Exposed Oak Forests & 81.3 & 55.97 & 14.2 & 15 \\
\hline Protected Oak Forests & 59 & 45.48 & 17.8 & 18 \\
\hline
\end{tabular}

Equation for calculating sample size was: $n=(1.645)^{2} * s^{2} / d^{2}$ (USDI NPS 1992)

$\mathrm{s}=$ Standard Deviation $\quad \mathrm{d}=\mathrm{x} * \mathrm{R} / 100, \quad$ where $\mathrm{x}=$ Mean and $\mathrm{R}=$ Level of precision (\%)

* Sample size was calculated to determine a $90 \%$ confidence of detecting at least a $30 \%$ change in stem density.

Figure 3. Location of deer browse and exclosure plots.

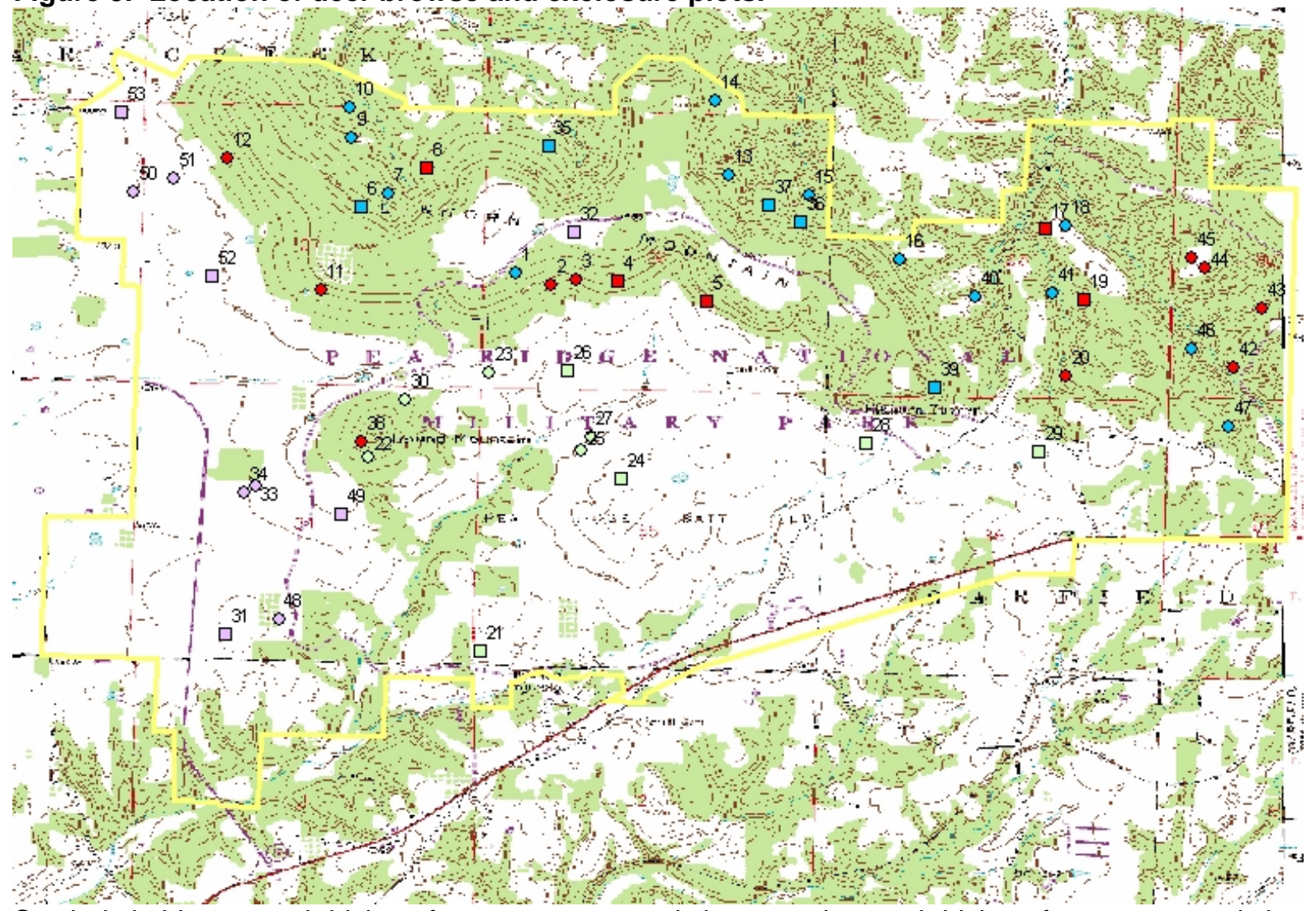

Symbols in blue are oak-hickory forests on protected slopes, red are oak-hickory forests exposed slopes, green are cedar thickets, and purple are old fields. All plots were used in the browse survey. Plots identified with squares also include exclosures. 


\section{Browse Survey (Objectives 4 and 5)}

Within the 10 x 10 m understory subplots used for community characterization, we surveyed deer browse using techniques similar to Strole and Anderson (1992) and Anderson and Loucks (1979). We conducted the browse survey over two years, sampling overstory trees in the first year only, and understory and groundflora both years. For woody species, we tallied all browsed and unbrowsed twigs between $0.152 \mathrm{~m}$ and 2.1 meters for each stem encountered. For groundflora, we recorded the number of browsed and unbrowsed stems for those species with evidence of browse.

\section{Exclosures Sampling (Objectives 6 and 7)}

After the first year of sampling, deer exclosures were constructed on a subset of deer browse survey plots. Five plots were randomly selected within each vegetation type for the construction of a $10 \mathrm{~m}$ x $10 \mathrm{~m}$ exclosure around the previously sampled northeast corner subplot (Figure 2). We built exclosures approximately eight feet high using $10 \mathrm{ft}$. steel corner and center posts, and $4 \mathrm{ft}$. tall woven wire fencing and high-tension wire. This exclosed subplot was paired with a unexclosed subplot located in the southwest corner within which vegetation was sampled both years using the methods described above. The location of groundflora subplots allowed us to sample vegetation within exclosures away from the fence line and avoid error due to fence line browsing (Russell et al. 2001). This sampling approach provided both pre- and post-exclosure data for both subplots; the southwest subplot was unexclosed for both sampling seasons, while the northeast subplot was unexclosed for the first year and exclosed for the second year. 


\section{Data Analysis}

\section{Vegetation Community Analysis (Objectives 1-3)}

Overstory tree density and basal area (Objective 1)

One-way analysis of variance (ANOVA) models were used to estimate and compare mean basal area per hectare and mean density per hectare of live trees among vegetation communities. The mixed models procedure (PROC MIXED) in SAS (SAS 1999) was used to fit a homogenous variance model and a heterogeneous variance model for each variable (Littell et al. 1996, Verbeke and Molenberghs 1997). The homogeneous variance model assumes constant variance among communities, and therefore, only allows the mean to be affected by community. The heterogeneous variance model assumes unequal variances for each community, and therefore, allows both the mean and variance to be affected by community. Akaike's Information Criterion for small samples (AICc; Burnham and Anderson 2002) was used to determine which of these models was most appropriate (Littell et al. 1996). The selected model was then used to compute estimates (i.e., least-squares means) of the response variable for each community. Fisher's protected least significant differences were used to compare least-squares means following significant effects in the ANOVAs (Milliken and Johnson, 1992). A significance level of 0.05 was used when reporting the results.

Understory tree and shrub density, height, and species richness (Objective 2)

A repeated measures ANOVA was used to estimate and compare mean understory density per hectare, average height, and species richness among the four vegetation communities. Year was the repeated measure factor. PROC MIXED of SAS (SAS 1999) was used to model the covariance structure of the repeated measures and to model the heterogeneity of this 
covariance structure among communities (Littell et al. 1996). Compound symmetry (i.e., years have equal variances) and unstructured (i.e., years have unequal variances) covariance matrices were used to model the repeated measures. For each of these covariance structures, two models were fit: 1) a model with the same covariance matrix for all communities and 2) a model with a different covariance matrix for each community. This resulted in four competing models. AICc was used to determine the most appropriate model (Littell et al. 1996). The selected model was then used to compute estimates (i.e., least-squares means) of the response variable for each community and year. Fisher's protected least significant differences were used to compare leastsquares means following significant effects in the ANOVAs (Milliken and Johnson, 1992). A significance level of 0.05 was used when reporting the results.

Old field understory vegetation was sampled using a smaller plot than the other vegetation communities. This should not have affected the analyses for density and average height, but may have had an effect on the analysis of species richness (as the area sampled increases, the potential for observing more species increases). If old fields were found to have lower species richness than the other three vegetation communities, this could be due to the smaller sampling area for old fields.

Understory tree and shrub density and species richness by regeneration height classes (Objective 2, continued)

A split-plot with repeated measures ANOVA was used to estimate and compare mean density per hectare and species richness among four vegetation communities and three height classes (Class $1=0.152-0.99 \mathrm{~m}$; Class $2=1.0-1.99 \mathrm{~m}$, Class $3 \geq 2.0 \mathrm{~m}$ ). Year was the repeated measure factor. PROC MIXED of SAS (SAS 1999) was used to model the covariance structure of the repeated measures and to model the heterogeneity of this covariance structure 
among community and height class combinations (Littell et al. 1996). Compound symmetry and unstructured covariance matrices were used to model the repeated measures. For each of these covariance structures, two models were fit: 1) a model with the same covariance matrix for all community/height class combinations and 2) a model with a different covariance matrix for each combination. This resulted in four competing models. AICc was used determine which of these models was more appropriate (Littell et al. 1996). The selected model was then used to compute estimates (i.e., least-squares means) of the response variable for each community, height class, and year. Fisher's protected least significant differences were used to compare least-squares means following significant effects in the ANOVAs (Milliken and Johnson, 1992). A significance level of 0.05 was used when reporting the results.

Old field understory vegetation was sampled using a smaller plot than the other vegetation communities. This should not have affected the analysis for density, but may have an effect on the analysis of species richness (as the area sampled increases, the potential for observing more species increases). If old fields were found to have lower species richness than the other three vegetation communities, this could be due to the smaller sampling area for old fields.

Groundflora species richness and percent cover (Objective 3)

Groundflora data were collected from four 1x1 m quadrats in each plot. Species richness and percent cover were computed for each quadrat. Prior to analysis, the quadrat values for percent cover in each plot and each year were averaged. The total number of species observed in the four quadrats combined was used for the analysis of species richness. A repeated measures ANOVA was used to estimate and compare percent cover and species richness among the four vegetation communities. Year was the repeated measure factor. PROC MIXED of SAS (SAS 
1999) was used to model the covariance structure of the repeated measures and to model the heterogeneity of this covariance structure among communities (Littell et al. 1996). Compound symmetry and unstructured covariance matrices were used to model the repeated measures. For each of these covariance structures, two models were fit: 1) a model with the same covariance matrix for all communities and 2) a model with a different covariance matrix for each community. This resulted in four competing models. AICc was used determine which of these models was more appropriate (Littell et al. 1996). The selected model was then used to compute estimates (i.e., least-squares means) of the response variable for each community and year. Fisher’s protected least significant differences were used to compare least-squares means following significant effects in the ANOVAs (Milliken and Johnson, 1992). A significance level of 0.05 was used when reporting the results.

\section{Browse Survey Analysis (Objectives 4 and 5)}

Following procedures described by Strole and Anderson (1992), we calculated the following values for individual species:

- Percent of Available Twigs Browsed (PATB) $=\frac{\# \text { of twigs browsed for a species }}{\text { Total number of twigs for a species }}$ X 100

- $\quad$ Relative Abundance $=$ \# of twigs for a species $\div$ \# twigs in plot (all species)

- $\quad$ Relative Use $=$ \# twigs browsed for a species $\div$ \# twigs browsed in plot (all species)

- $\quad$ Standardized Selection Ratio $=$ PATB $\div$ sum of all PATB’s for a community

We also calculated the combined species browse frequency for the plot as a whole, as well as within the three height classes described above. 
We used standardized selection ratios to determine which species were "preferentially" browsed. A standardized selection ratio (SSR) is the estimated probability that species $i$ would be the next species selected if it was possible to make each species equally available (Manly et. al 2002). SSRs are less sensitive to the effects of abundant but rarely used species. Values greater than $1 /$ (number of species) indicate preference, values below indicate avoidance, and values equal to indicate no preference.

Generalized linear mixed models (GLMMs; Littell et al. 1996) were used to identify factors that influenced the proportion of twigs browsed. GLMMs allow non-normal error structures and both fixed and random effects in the model. Random effects can be incorporated to provide covariance parameters needed when observations are grouped in clusters. The twigs within a plot are considered a cluster sample because the browse status (browsed or not browsed) of twigs within a plot may be correlated. Therefore, the proportion of twigs browsed was analyzed as a binomial response variable with random terms to account for the correlation among twigs within a plot. The proportion of twigs browsed was modeled as a generalized linear mixed model with a binomial error distribution and a logit link function, using the GLIMMIX macro in SAS (Littell et al. 1996).

The effect of vegetation community on the proportion of twigs browsed was modeled using a repeated measures model, with year as the repeated factor. The effects of species group or height class were examined using a split plot with repeated measures design. Plot was the whole-plot in the model; vegetation community was included in the model as the "treatment" applied to the whole plot. Species group or height class was the sub-plot and year was the repeated measure. A probability level of $P \leq 0.05$ was used as the significance criterion when reporting results. 


\section{Exclosure Analysis (Objectives 6 and 7)}

A split plot analysis of covariance (ANCOVA) model was used to compare density, height, and species richness of the understory and species richness and percent cover of the groundflora between exclosed and unexclosed areas (Milliken and Johnson 2002). The 20x20 m

plots were the whole-plots (or large sized experimental units) and exclosed and unexclosed areas within each plot were the subplots (or small sized experimental units) in the model. All variables were measured in each subplot in 2002 before the exclosures were built and then again in 2003 after the exclosures were built, resulting in pre- and post-exclosure data. The pre-exclosure data was used as the covariate in the model and the post-exclosure data was the response variable (Bonate 2000). Therefore, the post-exclosure data was compared between exclosed and unexclosed areas while adjusting for pre-exclosure differences. However, one assumption of ANCOVA is that a covariate measured on the smaller sized experimental unit is not affected by "treatment” (i.e., vegetation community) applied to the larger sized experimental unit. This assumption is not met with these data. Therefore, prior to analysis, the covariates were adjusted by centering them at zero for each community (Milliken and Johnson 2002).

The mixed models procedure (PROC MIXED) of SAS (SAS 1999) was first used to determine the covariance structure of the data (Milliken and Johnson 2002). The following homogenous and heterogeneous variance models were fit for each variable: 1) a model with the same covariance structure for each community and equal variances for exclosed and unexclosed areas, 2) a model with a different covariance structure for each community but equal variances for exclosed and unexclosed areas within community, 3) a model with the same covariance structure for each community but unequal variances for exclosed and unexclosed areas, and 4) a model with a different covariance structure for each community and unequal variances for 
exclosed and unexclosed areas within community. Akaike’s Information Criterion for small samples (AICc; Burnham and Anderson 2002) was used to determine which of these four models was most appropriate (Littell et al. 1996).

Using the selected model from above, the correct form of the covariate was determined using PROC MIXED (SAS 1999) and techniques in Milliken and Johnson (2002). The first step was to test if the relationship between the adjusted covariate and the response variable was the same for all combinations of vegetation community and exclosure status (Littell et al. 1996, Milliken and Johnson 2002). If the relationship was the same for all combinations, then a common slope parameter (i.e., the same slope parameter for all combinations of community and exclosure status) was used in the model. If the relationship was not the same for all combinations, the following hypotheses were tested: 1) a different slope parameter was needed for each community by exclosure status combination, 2) a different slope parameter was needed for each community, and 3) a different slope parameter was needed for each exclosure status. If hypothesis 1 was rejected, separate slope parameters were retained for each community by exclosure status combination. Separate slope parameters were included for each community if hypothesis 2 was rejected. If hypothesis 3 was rejected, separate slope parameters were included for each exclosure status. A common slope parameter was used in the model if none of the hypotheses were rejected.

Using the final model, the effects of exclosure status on the response variable were tested. If a common slope was used for exclosed and unexclosed areas, the comparison of exclosed and unexclosed will be the same at all values of the covariate. Therefore, the standard F-tests were used to test the significance of exclosure status. If different slopes were needed for exclosed and 
unexclosed areas, least squares means for exclosed and unexclosed area were compared at three values of the covariate. A significance level of 0.05 was used when reporting all results. 


\section{Results}

\section{Vegetation Community Analysis}

Overstory, understory, and groundflora vegetation were compared between the four vegetation communities to determine what, if any, differences existed between the communities. The communities were compared by overstory density and basal area; understory density, height, and species richness; understory density and richness by three height classes; and groundflora species richness and percent cover. Thirty five overstory species and 46 understory species were sampled within PERI. We found one overstory exotic species, Maclura pomifera (Moore 1999), and one understory exotic species, Rosa multiflora. Notable exotic species recorded in the groundflora include Rosa multiflora, Lespedeza cuneata, and Lonicera japonica.

Vegetation data were collected during the 2002 and 2003 growing season but at different times during the growing season. In 2002 data were collected in June, July, and August and in 2003 data were collected in August only. The different sampling periods will not affect the understory data. The understory trees and shrubs are persistent plants that retain their above ground structures all year long. Understory density and richness can be determined regardless of the season sampled. The groundflora data richness and cover data can be affected by the different sampling periods. Groundflora species richness and cover changes throughout the growing season due to species life-history traits and environmental conditions.

\section{Overstory Tree Analysis (Objective 1)}

Overstory density and basal area were significantly different among vegetation communities $\left(\mathrm{F}_{3,49}=97.13, \mathrm{P}<0.001\right.$ and $\mathrm{F}_{3,49}=232.18, \mathrm{P}<0.001$ respectively, Table 2). Cedar thickets had a tree density of 1325 stems/ha, which was significantly greater than values from all 
Table 2. Comparison of overstory conditions by vegetation community.

\begin{tabular}{lcccc}
\hline Community & \multicolumn{2}{c}{ Density (Stems/Hectare) } & \multicolumn{2}{c}{ Basal Area $\left(\mathbf{m}^{2} /\right.$ Hectare) } \\
\cline { 2 - 5 } & Mean & S.E. & Mean & S.E. \\
\hline Old Field & $37.5 \mathrm{a}$ & 18.5 & $0.85 \mathrm{a}$ & 0.33 \\
Cedar Thicket & $1325.0 \mathrm{~b}$ & 154.6 & $25.06 \mathrm{~b}$ & 2.49 \\
Exposed Oak Forest & $761.7 \mathrm{c}$ & 66.0 & $25.68 \mathrm{~b}$ & 1.52 \\
Protected Oak Forest & $775.0 \mathrm{c}$ & 59.3 & $23.9 \mathrm{~b}$ & 1.09 \\
\hline
\end{tabular}

Values in the same column with different letters are significantly different $(\alpha=0.05)$. Density and basal area were significantly different among vegetation communities $\left(F_{3,49}=97.13, P<0.001\right.$ and $F_{3,49}=232.18$, $P<0.001$ respectively).

other communities (all $\mathrm{P}<0.002$ ). Oak forests had densities that were statistically similar to one another (approximately 770 stems/ha) $(\mathrm{P}=0.88)$, but greater than old fields (37.5 stems/ha).

Basal area in old fields $\left(0.85 \mathrm{~m}^{2} / \mathrm{ha}\right)$ was significantly lower than in all other communities (approximately $25 \mathrm{~m}^{2} / \mathrm{ha}$ ) (all $\left.\mathrm{P}<0.001\right)$.

Quercus stellata and Quercus velutina were the most common species encountered within exposed oak forests, while Cornus florida, Quercus alba, and Quercus velutina were the most common trees within the protected oak forests. Cedar was abundant in both old fields and cedar thickets. The most frequent species from each community type are shown in Table 3. 
Table 3. The five most frequent overstory species in each community.

\begin{tabular}{|c|c|c|c|c|c|}
\hline Community & Species & Freq. & $\begin{array}{c}\text { Basal Area } \\
\left(\mathrm{m}^{2} / \text { Hectare }\right)\end{array}$ & $\begin{array}{c}\text { Density } \\
\text { (stems/ha) }\end{array}$ & Mean DBH (cm) \\
\hline \multirow{5}{*}{$\begin{array}{l}\frac{0}{0} \\
\frac{1}{4} \\
\frac{0}{0}\end{array}$} & Juniperus virginiana & 0.40 & 0.50 & 20.0 & 15.9 \\
\hline & Ulmus alata & 0.10 & 0.11 & 10.0 & 12.6 \\
\hline & Ulmus americana & 0.10 & 0.18 & 2.5 & 14.5 \\
\hline & Quercus velutina & 0.10 & 0.05 & 2.5 & 16.6 \\
\hline & Diospyros virginiana & 0.10 & 0.01 & 2.5 & 6.4 \\
\hline \multirow{5}{*}{ 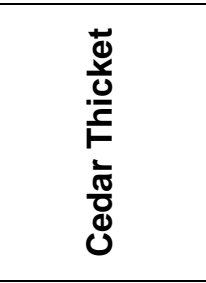 } & Juniperus virginiana & 0.90 & 11.18 & 507.5 & 14.8 \\
\hline & Cornus florida & 0.80 & 1.36 & 185.0 & 9.0 \\
\hline & Sassafras albidum & 0.70 & 0.66 & 80.0 & 8.8 \\
\hline & Quercus stellata & 0.60 & 4.03 & 230.0 & 13.8 \\
\hline & Quercus velutina & 0.50 & 2.89 & 47.5 & 20.9 \\
\hline \multirow{5}{*}{ 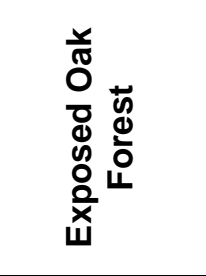 } & Quercus stellata & 0.87 & 11.46 & 271.7 & 18.9 \\
\hline & Quercus velutina & 0.67 & 4.94 & 73.3 & 25.2 \\
\hline & Cornus florida & 0.60 & 0.64 & 101.7 & 8.0 \\
\hline & Quercus alba & 0.60 & 4.93 & 66.7 & 25.1 \\
\hline & Quercus marilandica & 0.53 & 1.68 & 40.0 & 20.6 \\
\hline \multirow{5}{*}{ 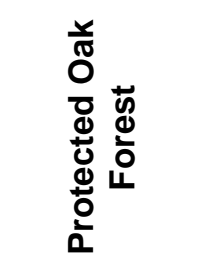 } & Cornus florida & 0.94 & 1.03 & 161.1 & 8.5 \\
\hline & Quercus alba & 0.89 & 7.48 & 130.6 & 22.9 \\
\hline & Quercus velutina & 0.89 & 6.99 & 101.4 & 26.7 \\
\hline & Carya tomentosa & 0.78 & 0.95 & 76.4 & 10.4 \\
\hline & Quercus stellata & 0.56 & 4.49 & 72.2 & 23.8 \\
\hline
\end{tabular}

\section{Understory Tree and Shrub Analysis (Objective 2)}

\section{Understory density}

Density per hectare differed significantly among communities $\left(F_{3,49}=8.39, P<0.001\right.$, Table 4$)$ and years $\left(F_{1,49}=5.84, P=0.019\right.$, Table 5$)$. Mean density per hectare was significantly lower in 2003 than in 2002. Old fields had the highest mean density and were significantly different than the other three communities (all $P<0.001$ ). Woody understory vegetation in cedar thickets had a mean density which was significantly higher than protected oak forests $(P=0.036)$ but not significantly different than exposed oak forests $(P=0.399)$. Understory vegetation 
densities for exposed oak forests and protected oak forests did not significantly differ from each other $(P=0.317)$.

Table 4. Comparison of woody understory vegetation by community with sample years combined.

\begin{tabular}{lcccccc}
\hline Community & \multicolumn{2}{c}{ Density (Stems/ha) } & \multicolumn{2}{c}{ Height (m) } & \multicolumn{2}{c}{ Richness } \\
\cline { 2 - 7 } & Mean & S.E. & Mean & S.E. & Mean & S.E. \\
\hline Old Field & $28750.0 \mathrm{a}$ & 4633.2 & $0.744 \mathrm{a}$ & 0.078 & $4.85 \mathrm{a}$ & 1.1 \\
Cedar Thicket & $10450.0 \mathrm{~b}$ & 1769.6 & $0.385 \mathrm{~b}$ & 0.052 & $10.7 \mathrm{~b}$ & 1.1 \\
Exposed Oak Forest & $8193.3 \mathrm{bc}$ & 1973.5 & $0.338 \mathrm{~b}$ & 0.025 & $9.67 \mathrm{~b}$ & 0.9 \\
Protected Oak Forest & $5866.7 \mathrm{c}$ & 1185.1 & $0.570 \mathrm{a}$ & 0.064 & $9.08 \mathrm{~b}$ & 0.8 \\
\hline
\end{tabular}

Values in the same column with different letters are significantly different $(\alpha=0.05)$. Density/hectare, height, and richness were significantly different among vegetation communities $\left(F_{3,49}=8.39, P<0.001\right.$; $F_{3,49}=10.94, P<0.001 ; F_{3,49}=5.67, P=0.002$, respectively).

Table 5. Summary of woody understory vegetation by sample year and vegetation community.

\begin{tabular}{lccccc}
\hline $\begin{array}{l}\text { Vegetation } \\
\text { Measure }\end{array}$ & $\begin{array}{c}\text { Sample } \\
\text { Year }\end{array}$ & \multicolumn{4}{c}{ Vegetation Community } \\
\cline { 3 - 6 } & & $\begin{array}{c}\text { Old } \\
\text { Field }\end{array}$ & $\begin{array}{c}\text { Cedar } \\
\text { Thicket }\end{array}$ & $\begin{array}{c}\text { Exposed Oak } \\
\text { Forest }\end{array}$ & $\begin{array}{c}\text { Protected Oak } \\
\text { Forest }\end{array}$ \\
\hline \multirow{2}{*}{ Density/Hectare } & $2002^{*}$ & 31880.0 & 11540.0 & 9433.33 & 5872.22 \\
& $2003^{*}$ & 25620.0 & 9360.0 & 6953.33 & 5861.11 \\
\hline \multirow{2}{*}{ Height (m) } & 2002 & 0.735 & 0.370 & 0.341 & 0.555 \\
& 2003 & 0.752 & 0.400 & 0.336 & 0.585 \\
\hline \multirow{2}{*}{ Richness } & 2002 & 5.0 & 10.4 & 10.3 & 9.2 \\
& 2003 & 4.7 & 11.0 & 9.0 & 8.9 \\
\hline
\end{tabular}

* indicates significant difference between years at $\alpha=0.05$.

Understory height

Average height significantly differed among communities $\left(F_{3,49}=10.94, P<0.001\right.$, Table 4), but not between years $\left(F_{1,49}=1.29, P=0.262\right.$, Table 5). Average heights for cedar thickets and exposed oak forests did not significantly differ from each other $(P=0.418)$, but were significantly less than the average heights for protected oak forests and old fields (all $P<0.04$ ). Average height for protected oak forests did not significantly differ from old fields $(P=0.092)$. 


\section{Understory species richness}

Species richness significantly differed among communities $\left(F_{3,49}=5.67, P=0.002\right.$, Table 4), but not between years $\left(F_{1,49}=0.93, P=0.341\right.$, Table 5$)$. Understory species richness for old fields was significantly less than richness for the other three communities (all $P<0.004$ ), this may be due to the smaller sampling area in old fields than the other communities. Cedar, exposed oak forests, and protected oak forests mean species richness did not significantly differ from each other (all $P>0.2$ ). The most frequent understory species from each community are shown in Table 6.

Understory density by height class

Mean density significantly differed among community by height class combinations $\left(F_{6,98}=4.32, P<0.001\right.$, Table 7$)$ and among height class by year combinations $\left(F_{2,147}=3.49\right.$, $P=0.033)$, but not among community by year combinations $\left(F_{3,147}=1.86, P=0.138\right)$. Mean density for height class 1 was significantly higher than for height classes 2 and 3 for all communities (all $P<0.001$ ). Mean density for height class 2 was significantly different than class 3 for exposed oak forest $(P=0.043)$, old fields $(P=0.033)$, and protected oak forests $(P<0.001)$, but not for cedar $(P=0.395)$. 
Table 6. Understory species with the highest two-year mean densities in each community type.

\begin{tabular}{|c|c|c|c|}
\hline Community & Species & Mean Frequency & Mean Density (Stems/ha) \\
\hline \multirow{6}{*}{ 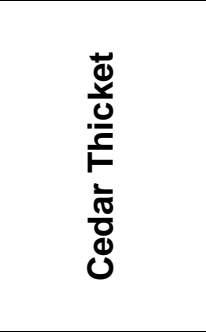 } & Fraxinus americana & 60.0 & 2045.0 \\
\hline & Symphoricarpos orbiculatus & 100.0 & 2810.0 \\
\hline & Quercus velutina & 65.0 & 1075.0 \\
\hline & Quercus stellata & 75.0 & 1190.0 \\
\hline & Juniperus virginiana & 50.0 & 650.0 \\
\hline & Rhamnus caroliniana & 60.0 & 590.0 \\
\hline \multirow{6}{*}{$\begin{array}{l}\frac{n}{0} \\
\frac{0}{0} \\
\frac{0}{0}\end{array}$} & Rubus pensilvanicus & 85.0 & 12130.0 \\
\hline & Rhus copallina & 85.0 & 8595.0 \\
\hline & Symphoricarpos orbiculatus & 70.0 & 8105.0 \\
\hline & Diospyros virginiana & 45.0 & 620.0 \\
\hline & Ulmus alata & 35.0 & 1825.0 \\
\hline & Sassafras albidum & 45.0 & 2040.0 \\
\hline \multirow{6}{*}{ 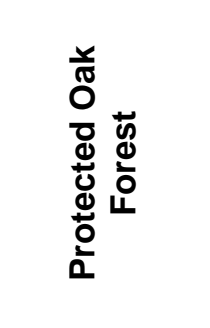 } & Diospyros virginiana & 58.3 & 200.0 \\
\hline & Symphoricarpos orbiculatus & 58.3 & 713.9 \\
\hline & Rubus pensilvanicus & 55.6 & 538.9 \\
\hline & Cornus florida & 55.6 & 522.2 \\
\hline & Fraxinus Americana & 50.0 & 355.6 \\
\hline & Ulmus alata & 55.6 & 322.2 \\
\hline \multirow{6}{*}{ 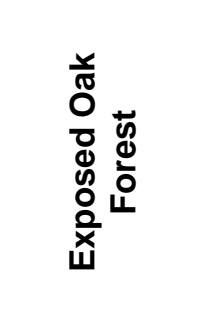 } & Carya texana & 53.3 & 143.3 \\
\hline & Quercus stellata & 73.3 & 1586.7 \\
\hline & Symphoricarpos orbiculatus & 53.3 & 860.0 \\
\hline & Vaccinium stamineum & 53.3 & 516.7 \\
\hline & Cornus florida & 46.7 & 303.3 \\
\hline & Quercus velutina & 86.7 & 430.0 \\
\hline
\end{tabular}

Table 7. Mean woody understory density by height class and vegetation community, both sample years combined.

\begin{tabular}{lcccccc}
\hline Community & \multicolumn{5}{c}{ Density (Stems/ ha) } \\
\cline { 2 - 7 } & \multicolumn{5}{c}{ Height Class } \\
\cline { 2 - 6 } & \multicolumn{1}{c}{$1(0.152-0.99 \mathrm{~m})$} & $2(1.0-1.99 \mathrm{~m})$ & $3(\geq 2.0 \mathrm{~m})$ \\
\cline { 2 - 6 } & Mean & S.E. & Mean & S.E. & Mean & S.E. \\
\hline Old Field & $22870 \mathrm{a}(\mathrm{x})$ & 4249.9 & $4945 \mathrm{~b}(\mathrm{x})$ & 1731.5 & $935 \mathrm{c}(\mathrm{xy})$ & 676.6 \\
Cedar Thicket & $9655 \mathrm{a}(\mathrm{y})$ & 1637.5 & $315 \mathrm{~b}(\mathrm{y})$ & 118.3 & $480 \mathrm{~b}(\mathrm{xy})$ & 152.5 \\
Exposed Oak Forest & $7906.7 \mathrm{a}(\mathrm{yz})$ & 1983.6 & $60 \mathrm{~b}(\mathrm{z})$ & 21.7 & $226.7 \mathrm{c}(\mathrm{y})$ & 78.3 \\
Protected Oak Forest & $5236.1 \mathrm{a}(\mathrm{z})$ & 1206.5 & $100.0 \mathrm{~b}(\mathrm{yz})$ & 43.4 & $530.6 \mathrm{c}(\mathrm{x})$ & 88.9 \\
\hline
\end{tabular}

Letters $a, b$ and $c$ represent comparisons within vegetation community between height classes. Letters $x$, $\mathrm{y}$ and $\mathrm{z}$ represent comparisons within height class between vegetation communities. Different letters represents a significant difference $(\alpha=0.05)$. Mean density differed significantly among community by height class $\left(F_{6,98}=4.32, P=0.001\right)$. 
For height class 1, old fields had a significantly higher density than the other three communities (all $P<0.005$ ). Cedar had significantly higher density than protected oak forests ( $P=0.032$ ), but not exposed oak forests $(P=0.498)$. Mean density for exposed oak forests was not significantly different than protected oak forests $(P=0.253)$. For height class 2 , old fields had significantly higher density than the other three communities (all $P<0.01$ ). Cedar had significantly higher density than exposed oak forests $(P=0.037)$, but not protected oak forests $(P=0.091)$. Mean density for exposed oak forests was not significantly different than protected oak forests $(P=0.412)$. For height class 3 , exposed oak forests and protected oak forests had significantly different mean densities $(P=0.012)$, but neither were significantly different from cedar and old fields, which do not significantly differ from each other (all $P>0.1$ ).

Density in 2002 was significantly higher than in 2003 for height class $1(P=0.051)$, but not height class $2(P=0.061)$ or $3(P=0.726)$. Mean density for height class 1 was significantly higher than height classes 2 and 3 both years (all $P<0.001$ ). Mean density for height classes 2 and 3 were significantly different in $2002(P=0.048)$ but not $2003(P=0.261)$.

\section{Understory species richness by height class}

Mean species richness significantly differed among community by height class combinations ( $F_{6,98}=9.26, P<0.001$, Table 8 ), but not between years, among year by community combinations, or among year by height class combinations (all $P>0.07$ ). Species richness for height class 1 was significantly higher than for height classes 2 and 3 for all communities (all $P<0.001)$. Means species richness for height class 2 was significantly different than class 3 for exposed oak forest $(P=0.022)$, old fields $(P=0.002)$, and protected oak forests $(P<0.001)$, but not 
Table 8. Mean woody understory species richness by height class and vegetation community, both sample years combined.

Community

Species Richness

Height Class

\begin{tabular}{lcccccc}
\cline { 2 - 7 } & \multicolumn{2}{c}{$1(0.152-0.99 m)$} & \multicolumn{2}{c}{$2(1.0-1.99 m)$} & \multicolumn{2}{c}{$3(\geq 2.0 \mathrm{~m})$} \\
\cline { 2 - 7 } & Mean & S.E. & Mean & S.E. & Mean & S.E. \\
\hline Old Field & $4.6 \mathrm{a}(\mathrm{x})$ & 0.56 & $1.8 \mathrm{~b}(\mathrm{y})$ & 0.38 & $0.35 \mathrm{c}(\mathrm{x})$ & 0.25 \\
Cedar Thicket & $9.9 \mathrm{a}(\mathrm{y})$ & 1.54 & $1.5 \mathrm{~b}(\mathrm{y})$ & 0.47 & $2.3 \mathrm{~b}(\mathrm{yz})$ & 0.49 \\
Exposed Oak Forest & $9.2 \mathrm{a}(\mathrm{y})$ & 0.93 & $0.4 \mathrm{~b}(\mathrm{x})$ & 0.12 & $1.2 \mathrm{c}(\mathrm{y})$ & 0.32 \\
Protected Oak Forest & $8.1 \mathrm{a}(\mathrm{y})$ & 0.73 & $0.4 \mathrm{~b}(\mathrm{x})$ & 0.13 & $2.2 \mathrm{c}(\mathrm{z})$ & 0.32 \\
\hline
\end{tabular}

Letters $a, b$ and $c$ represent comparisons within vegetation communities between height classes. Letters $x, y$ and $z$ represent comparisons within height class between vegetation communities. Different letters represents a significant difference $(\alpha=0.05)$. Mean species richness differed significantly among community by height class $\left(F_{6,98}=9.26, P=0.001\right)$.

for cedar $(P=0.244)$. Old fields were sampled using small plots than the other communities and therefore may have lower species richness.

For height class 1, species richness for old fields was significantly less than for the other three communities (all $P<0.002$ ), which did not significantly differ from each other (all $P>0.3$ ). For height class 2, species richness for protected oak forests and exposed oak forests did not significantly differ from each other $(P=0.95)$, but were significantly less than cedar and old fields (all $P<0.03$ ). Species richness in cedar and old fields did not significantly differ from each other $(P=0.62)$. For height class 3, old fields had significantly lower species richness than the other three communities (all $P<0.04)$.

\section{Groundflora Analysis (Objective 3)}

\section{Groundflora species richness}

Species richness significantly differed among communities $\left(F_{3,49}=14.03, P<0.001\right)$, but not years $\left(F_{1,49}=2.79, P=0.101\right)$. Species richness for old fields was 37.5 ( $\left.\mathrm{SE}=2.49\right)$, 
significantly higher than the other three communities (all $P<0.01$ ). Cedar had a species richness of 27.6 ( $\mathrm{SE}=2.49$ ), which was significantly greater than forested communities (all $P<0.03$ ). Exposed oak forest and protected oak forest had mean species richness of 20.3 (SE=2.03) and 19.0 (SE=1.85), respectively, and did not significantly differ from each other $(P=0.640)$. Groundflora data were collected at different times during the 2002 and 2003 sampling years, patterns in groundflora richness may have been affected by different sampling periods.

\section{Groundflora percent cover}

The model with the lowest AICc value for mean percent cover was the model with a different compound symmetry covariance matrix for each community ( $\triangle \mathrm{AICc} \geq 3.8$ ). Mean percent cover significantly differed among communities $\left(F_{3,49}=147.03, P<0.001\right)$ and between years $\left(F_{1,49}=11.76, P=0.001\right)$. Mean percent cover was significantly lower in 2003 than in 2002. The difference in cover between 2002 and 2003 may be a result of different sampling periods for each year. Groundflora was sampled in June. July, and August in 2002 and only in August in 2003. Old fields had mean percent cover of 125.4 ( $S E=4.01)$, which was significantly higher than the other three communities (all $P<0.001$ ). (Total cover can exceed 100 percent due to overlapping vegetation and due to the coarse cover classes used.) Cedar, exposed oak forests, and protected oak forests had mean percent cover values of 30.2 (SE=7.53), 23.2 (SE=3.19), and 33.5 ( $\mathrm{SE}=4.58$ ), respectively, and do not significantly differ from each other (all $P>0.07$ ). 


\section{Browse Survey Analysis}

\section{Proportion of Twigs Browsed among Four Vegetation Communities (Objective 4)}

Overall comparison of proportion of twigs browsed between vegetation communities

The observed values for both total number of twigs and number of browsed twigs were extremely variable between years (Table 9). For example, total twigs recorded in exposed oak forests and cedar thickets decreased by two thirds and one half, respectively, between 2002 and 2003. (Values within protected oak forests and old fields were relatively similar between years, at around 7,000 and 25,000 twigs, respectively.) In old fields and cedar thickets, the total recorded number of browsed twigs increased by an order of magnitude from the first year to the second. Within protected oak forests, this number more than doubled during the same time, while increasing about 20 percent in exposed oak forests. Exposed oak forests consistently contained the highest number of browsed twigs, while old fields consistently contained the fewest number of browsed stems.

Table 9. Total twigs and total browsed twigs found in each community by year.

\begin{tabular}{lcccc}
\hline Community & \multicolumn{2}{c}{2002} & \multicolumn{2}{c}{$\mathbf{2 0 0 3}$} \\
\cline { 2 - 5 } & $\begin{array}{c}\text { Total \# } \\
\text { Twigs }\end{array}$ & $\begin{array}{c}\text { Total \# Browsed } \\
\text { Twigs }\end{array}$ & $\begin{array}{c}\text { Total \# } \\
\text { Twigs }\end{array}$ & $\begin{array}{c}\text { Total \# Browsed } \\
\text { Twigs }\end{array}$ \\
\hline Old Field & 22612 & 22 & 26609 & 253 \\
Cedar Thicket & 41511 & 58 & 22908 & 538 \\
Exposed Oak Forest & 20803 & 718 & 7335 & 870 \\
Protected Oak Forest & 6738 & 198 & 7335 & 494 \\
\hline
\end{tabular}

The proportion of twigs browsed differed significantly between years $\left(F_{1,49}=16.78\right.$, $P=0.0002$, Table 10) and among vegetation communities $\left(F_{3,49}=7.15, P=0.0004\right)$. The proportion of twigs browsed was greater in 2003 than in 2002. The proportion of twigs browsed in cedar 
and old fields was significantly less than in exposed oak forests and protected oak forests (all $P<0.01)$. Cedar thickets and old fields did not significantly differ from each other $(P=0.61)$, and exposed and protected oak forests do not significantly differ from each other $(P=0.55)$.

Table 10. Proportion of twigs browsed among four vegetation communities and between sampling years.

\begin{tabular}{|c|c|c|c|}
\hline Community & Year & Browse Frequency & 95\% Confidence Interval on Frequency \\
\hline Old Fields & --- & $0.00336(b)$ & $(0.00054,0.02047)$ \\
\hline Cedar & --- & $0.00584(b)$ & $(0.00175,0.01928)$ \\
\hline Exposed Oak & --- & $0.06042(a)$ & $(0.03750,0.09595)$ \\
\hline Protected Oak & --- & $0.04623(a)$ & $(0.02141,0.09700)$ \\
\hline--- & 2002 & 0.00664 & $(0.00256,0.01713)$ \\
\hline --- & 2003 & 0.03584 & $(0.02478,0.05157)$ \\
\hline
\end{tabular}

Different letters indicate significant differences between communities. The differences recorded between years are significant $(p=0.0002)$.

Proportion of twigs browsed between height classes among four vegetation communities

Height class 2 twigs were observed in 60\%, 47\%, 80\%, and 33\% of cedar, exposed oak, old field, and protected oak plots, respectively, in 2002. Percentages were similar for 2003 except for exposed oak where only 20\% of the plots had height class 2 twigs. In 2002, no twigs of height class 2 were browsed in cedar, old field, and protected oak plots. In 2003, all communities had some height class 2 twigs browsed. Height class 3 twigs were observed in $80 \%$ and $90 \%$ of the cedar plots, 60 and $67 \%$ of the exposed oak plots, and $78 \%$ and $94 \%$ of the protected oak plots in 2002 and 2003, respectively. Height class 3 twigs were rarely observed and never browsed in old fields. These factors caused many missing values and many zero values for the proportion of twigs browsed, with some combinations of height class, vegetation community, and year where values were either missing or zero. This caused convergence problems in GLIMMIX. Therefore, height classes 2 and 3 were combined into one class prior to analysis and old fields were dropped from the analysis. 
The proportion of twigs browsed differed significantly between years $\left(F_{1,69}=10.99\right.$, $P=0.0015$, Table 11$)$, among vegetation communities $\left(F_{2,36}=5.14, P=0.0109\right)$ and between height classes $\left(F_{1,36}=21.14, P<0.0001\right)$. The proportion of twigs browsed was greater for height class 1 than for height class $2+3$.

Table 11. Comparison of proportion of twigs browsed between height classes.

\begin{tabular}{ccc} 
Height Class & Browse Frequency & 95\% Confidence Interval on Frequency \\
\hline 1 & 0.05463 & $(0.03697,0.08002)$ \\
$2+3$ & 0.00430 & $(0.00148,0.01242)$ \\
\hline
\end{tabular}

\section{Deer Browse of Oak and Hickory Stems Compared to Other Species (Objective 5)}

Oak was observed in all exposed oak forest plots both years and in about half to twothirds of the protected oak forest plots and cedar plots each year. Oak was rarely observed in old field plots. Hickory was observed in over half the protected oak forest plots, over two-thirds of the exposed oak forests, and in about half of the cedar plots each year. However, hickory was never observed in old fields. When hickory was observed in a plot, it was not very abundant. Hickory was not browsed in cedar plots and rarely browsed in exposed oak plots. Oak was not browsed in the few old field plots in which it occurred. These factors caused many missing values and many zero values for the proportion of twigs browsed, with some combination of species, vegetation community, and year where values were either missing or zero. This caused convergence problems in GLIMMIX. Therefore, oak and hickory were combined into one species group (Table 12) prior to analysis and old fields were dropped from the analysis since they rarely had any oak or hickory twigs available. The proportion of twigs browsed differed significantly between years $\left(F_{1,72}=13.61, P=0.0004\right)$ and among vegetation communities $\left(F_{2,36}=3.43, P=0.0435\right)$, but not between species groups $\left(F_{1,36}=0.17, P=0.6798\right.$, Table 13$)$. 
Table 12. List of encountered species within the oak-hickory species group.

\begin{tabular}{ll|ll}
\hline \multicolumn{2}{c|}{ Oak (Quercus) Species } & \multicolumn{2}{c}{ Hickory (Carya) Species } \\
\hline White Oak & Q. alba & Bitternut Hickory & C. cordiformis \\
Scarlet Oak & Q. coccinea & Pignut Hickory & C. glabra \\
Blackjack Oak & Q. marilandica & Black Hickory & C. texana \\
Chinkapin Oak & Q. muehlenbergii & Mockernut Hickory & C. tomentosa \\
Red Oak & Q. rubra & & \\
Post Oak & Q. stellata & & \\
Black Oak & Q. velutina & & \\
\hline
\end{tabular}

Table 13. Comparison of proportion of twigs browsed between oak and hickory seedlings combined and all other species combined.

\begin{tabular}{ccc}
\hline Species Group & Browse Frequency & 95\% Confidence Interval on Frequency \\
\hline Oak + Hickory & 0.03868 & $(0.01808,0.08081)$ \\
Other & 0.03299 & $(0.02242,0.04830)$ \\
\hline
\end{tabular}

Few oak and hickory species met our definition of "preferentially browsed” (Table 14), which required that a species' standardized selection ratio (SSR) be greater than 1/number of species found in each community. There are no statistical tests or confidence intervals for the SSR ratios but SSR's provide a way to compare the probability a species would be browsed. In cedar thickets, no species from the oak and hickory species group were preferred browse species. In fact, Quercus stellata, Q. velutina, Q. marilandica, Q. muehlenbergii, Q. rubra, Carya texana, and C. tomentosa were classified as avoided. In exposed oak forests, Carya tomentosa and $C$. glabra were the only oak or hickory preferentially browsed species. In protected forests, Quercus coccinea and Q. stellata were the only oak or hickory species that were preferentially browsed.

Preferentially browsed species common to oak forests were Fraxinus americana, Rhamnus caroliniana and Rhus aromatica. Cedar was consistently classified avoided in oak. 
Table 14. Top five preferred and avoided species browsed within each vegetation community.

\begin{tabular}{|c|c|c|c|}
\hline Species* & SSR & Species* & SSR \\
\hline \multicolumn{2}{|c|}{ Preferred Species (SSR > 1/\# species) } & \multicolumn{2}{|c|}{ Avoided Species (SSR $<1$ /\# of species) } \\
\hline \multicolumn{4}{|c|}{ Old Field $(1 / \#$ of species $=1 / 17=0.059)$} \\
\hline Rosa caroliniana & 0.495 & Prunus americana & 0.018 \\
\hline \multirow[t]{4}{*}{ Rosa multiflora } & 0.274 & Diospyros virginiana & 0.014 \\
\hline & & Symphoricarpos orbiculatus & 0.012 \\
\hline & & Sassafras albidum & 0.003 \\
\hline & & Ulmus alata & 0.001 \\
\hline \multicolumn{4}{|c|}{ Cedar Thicket $(1 / \#$ species $=1 / 40=0.025)$} \\
\hline Vitis spp. & 0.187 & Carya texana & 0.000 \\
\hline Vitis vulpina & 0.176 & Cercis canadensis & 0.000 \\
\hline Prunus americana & 0.149 & Juniperus virginiana & 0.000 \\
\hline Parthenocissus quinquefolia & 0.134 & Quercus marilandica & 0.000 \\
\hline Viburnum rufidulum & 0.087 & Ulmus rubra & 0.000 \\
\hline \multicolumn{4}{|c|}{ Exposed Oak Forest $(1 / \#$ of species $=1 / 39=0.026)$} \\
\hline Vitis aestivalis & 0.205 & Quercus stellata & 0.015 \\
\hline Acer rubrum & 0.104 & Vaccinium stamineum & 0.015 \\
\hline Amelanchier arborea & 0.102 & Vaccinium vacillans & 0.013 \\
\hline Rhus aromatica & 0.091 & Cornus florida & 0.007 \\
\hline Nyssa sylvatica & 0.086 & Juniperus virginiana & 0.000 \\
\hline \multicolumn{4}{|c|}{ Protected Oak Forest $(1 / \#$ of species $=1 / 42=0.024)$} \\
\hline Cercis canadensis & 0.102 & Symphoricarpos orbiculatus & 0.011 \\
\hline Vitis vulpina & 0.097 & Cornus florida & 0.005 \\
\hline Bumelia lanuginosa & 0.083 & Quercus alba & 0.004 \\
\hline Rubus flagellaris & 0.069 & Ulmus alata & 0.003 \\
\hline Quercus coccinea & 0.064 & Lindera benzoin & 0.000 \\
\hline
\end{tabular}

* Bold type indicates oak (Quercus) and hickory (Carya) species.

forests and cedar thickets. Most tree species were browsed at varying levels across communities, and the browse intensity classification of these species was inconsistent.

Individual species browse patterns within PERI were variable between years except for a few species (Table 15). Quercus marilandica, Carya texana, Juniperus virginiana, Symphoricarpos orbiculatus, Vaccinium vacillans, Prunus americana and Sassafras albidum had the smallest change in PATB between years. Species for which the browse intensity varied the 
most between years included Vitis vulpina, Acer rubra, Nyssa sylvatica, Viburnum rufidulum,

Rhamnus caroliniana and Carya tomentosa.

Table 15. Individual species browse intensity by year for species with $\mathbf{5 0}$ or more recorded twigs.

\begin{tabular}{l|ccc|ccc}
\hline \multicolumn{1}{c|}{ Year } & \multicolumn{3}{c|}{2002} & & 2003 & \\
\hline Species* & PATB! & Relative & Relative & PATB & $\begin{array}{c}\text { Relative } \\
\text { Abundance }\end{array}$ & $\begin{array}{c}\text { Relative } \\
\text { use }\end{array}$ \\
\hline Acer rubra & 0.313 & 0.003 & 0.075 & 0.919 & 0.002 & 0.048 \\
Amelanchier arborea & 0.094 & 0.001 & 0.005 & 0.272 & 0.003 & 0.028 \\
Carya texana & 0.067 & 0.001 & 0.008 & 0.100 & 0.002 & 0.006 \\
Carya tomentosa & 0.100 & 0.001 & 0.006 & 0.277 & 0.001 & 0.007 \\
Celtis occidentalis & 0.084 & 0.001 & 0.006 & 0.097 & 0.003 & 0.008 \\
Cornus florida & 0.017 & 0.046 & 0.074 & 0.035 & 0.052 & 0.054 \\
Diospyros virginiana & 0.002 & 0.006 & 0.001 & 0.068 & 0.008 & 0.016 \\
Fraxinus americana & 0.038 & 0.006 & 0.022 & 0.151 & 0.009 & 0.044 \\
Juniperus virginiana & 0.000 & 0.430 & 0.000 & 0.000 & 0.273 & 0.000 \\
Nyssa sylvatica & 0.238 & 0.002 & 0.042 & 0.358 & 0.001 & 0.011 \\
Prunus americana & 0.022 & 0.001 & 0.002 & 0.024 & 0.044 & 0.032 \\
Quercus alba & 0.029 & 0.005 & 0.015 & 0.020 & 0.014 & 0.008 \\
Quercus marilandica & 0.000 & 0.005 & 0.000 & 0.032 & 0.006 & 0.006 \\
Quercus stellata & 0.047 & 0.014 & 0.064 & 0.096 & 0.021 & 0.059 \\
Quercus velutina & 0.036 & 0.006 & 0.022 & 0.093 & 0.009 & 0.027 \\
Rhamnus caroliniana & 0.017 & 0.012 & 0.019 & 0.030 & 0.012 & 0.011 \\
Rhus copallina & 0.002 & 0.007 & 0.001 & 0.056 & 0.012 & 0.019 \\
Rubus pensilvanicus & 0.013 & 0.009 & 0.012 & 0.082 & 0.013 & 0.032 \\
Sassafras albidum & 0.033 & 0.030 & 0.095 & 0.041 & 0.043 & 0.052 \\
Symphoricarpos orbiculatus & 0.012 & 0.078 & 0.090 & 0.049 & 0.193 & 0.284 \\
Ulmus alata & 0.000 & 0.222 & 0.013 & 0.007 & 0.217 & 0.046 \\
Ulmus rubra & 0.000 & 0.002 & 0.000 & 0.000 & 0.004 & 0.000 \\
Vaccinium stamineum & 0.055 & 0.015 & 0.078 & 0.145 & 0.007 & 0.032 \\
Vaccinium vacillans & 0.051 & 0.069 & 0.330 & 0.128 & 0.019 & 0.076 \\
Viburnum rufidulum & 0.000 & 0.002 & 0.000 & 0.166 & 0.001 & 0.007 \\
Vitis vulpina & 0.000 & 0.000 & 0.000 & 0.561 & 0.001 & 0.017 \\
\hline Bon & & & &
\end{tabular}

* Bold type indicates oak (Quercus) and hickory (Carya) species.

' PATB: Percent of Available Twigs Browsed 


\section{Exclosure Analysis}

\section{Understory Tree and Shrub Exclosure Analysis (Objective 6)}

\section{Understory stem density}

For mean density per hectare, the model with a different covariance structure for each community but equal variances for exclosed and unexclosed areas within community had the lowest AICc value ( $\triangle \mathrm{AICc} \geq 16.3$ ). A significant difference in the relationship between the adjusted covariate and mean density in 2003 was not detected among community by exclosure status combinations $\left(F_{7,8}=2.35, P=0.128\right)$; therefore, a common slope parameter was used for the adjusted covariate. A significant difference in mean density per hectare was detected between unexclosed and exclosed areas $\left(F_{1,15}=6.86, P=0.019\right)$. Unexclosed areas had significantly lower density than exclosed areas (Table 16.).

Table 16. Comparison of mean density and height by vegetation community and exclosure treatment.

\begin{tabular}{lcccccc}
\hline Community & \multicolumn{2}{c}{ Density/Hectare } & Mean Height (meters) & \multicolumn{2}{c}{ Richness } \\
\cline { 2 - 7 } & Exclosed & Unexclosed & Exclosed & Unexclosed & Exclosed & Unexclosed \\
\hline Old Field & 52564.00 & 34756.00 & 0.640 & 0.580 & 6.043 & 5.134 \\
Cedar Thicket & 13870.00 & 13610.00 & 0.426 & 0.478 & 15.526 & 17.576 \\
Exposed Oak Forest & 9124.66 & 6475.34 & 0.470 & 0.412 & $14.191^{\star}$ & $9.357^{\star}$ \\
Protected Oak Forest & 5439.50 & 3560.50 & 0.606 & 0.814 & 10.702 & 8.126 \\
\hline Mean all Communities & $20250.00^{*}$ & \multirow{2}{*}{$14600.00^{*}$} & \multirow{2}{*}{0.536} & 0.571 & 11.615 & \multirow{2}{*}{10.048} \\
Combined & & & & & & \\
\hline
\end{tabular}

* Significant Difference at $\alpha=0.05$

\section{Understory height}

For average height, the model with the same covariance structure for each community and unequal variances for exclosed and unexclosed areas had the lowest AICc value; however, the model with the same covariance structure for each community and equal variances for 
exclosed and unexclosed areas had an AICc value that differed by only 0.2 from the above model. Since the second model is more parsimonious, it was selected. A significant difference in the relationship between the adjusted covariate and average height in 2003 was not detected among community by exclosure status combinations $\left(F_{7,8}=1.05, P=0.466\right)$; therefore, a common slope parameter was used for the adjusted covariate. A significant difference in average height was not detected between exclosed and unexclosed areas $\left(F_{1,15}=0.70, P=0.415\right.$, Table 15$)$.

\section{Understory species richness}

The model with the same covariance structure for all communities and equal variances for exclosed and unexclosed areas had the lowest AICc value for mean species richness ( $\triangle \mathrm{AICc} \geq 7.3$ ). A significant difference in the relationship between the adjusted covariate and mean species richness in 2003 was detected among community by exclosure status combinations ( $\left.F_{7,8}=3.53, P=0.049\right)$; therefore, hypotheses that a different slope parameter was needed for each combination, for each community, and for each exclosure status were tested. Different slope parameters were needed for each community by exclosure status combination $(P=0.039)$. Since the relationship between the adjusted covariate and species richness is different for each community by exclosure combination, exclosed and unexclosed areas need to be compared at several values of the covariate (i.e., at several values of adjusted 2002 species richness). Therefore, exclosure statuses were compared at adjusted 2002 species richness equal to $0,-3$, and 3. Mean species richness in exclosed areas was significantly greater than in unexclosed areas for exposed oak forests at adjusted 2002 species richness equal to 0 and 3 (all $P<0.01$ ), but not at -3 $(P=0.38)$. Exclosed areas did not significantly differ from unexclosed areas for any of the other communities at any of the three values of adjusted 2002 species richness (all $P>0.06$, Table 16). 


\section{Groundflora Exclosure Analysis (Objective 7)}

Groundflora species richness

For mean species richness, the model with the same covariance structure for each community and equal variances for exclosed and unexclosed areas had the lowest AICc value ( $\triangle \mathrm{AICc} \geq 4.8$ ). A significant difference in the relationship between the adjusted covariate and mean species richness in 2003 was not detected among community by exclosure status combinations $\left(F_{7,8}=1.83, P=0.207\right)$; therefore, a common slope parameter was used for the adjusted covariate. Unexclosed areas had significantly lower species richness (9.8 species lower) than exclosed areas $\left(F_{1,15}=12.70, P=0.003\right)$.

\section{Groundflora cover}

The model with the same covariance structure for each community and equal variances for exclosed and unexclosed areas had the lowest AICc value for mean percent cover ( $\triangle \mathrm{AICc} \geq 7.3$ ). A significant difference in the relationship between the adjusted covariate and mean percent cover in 2003 was detected among community by exclosure status combinations $\left(F_{7,8}=7.54, P=0.005\right)$; therefore, hypotheses that a different slope parameter was needed for each combination, for each community, and for each exclosure status were tested. Different slope parameters were needed for each community $(P<0.01)$, but not for each exclosure status or each combination of community and exclosure status (all $P>0.2$ ). A significant difference in mean percent cover was not detected between exclosed and unexclosed areas $\left(F_{1,12}=0.66, P=0.431\right)$. 


\section{Discussion}

\section{Vegetation Community Analysis}

\section{Overstory Tree Analysis (Objective 1)}

The differences that we recorded in the overstory between communities reflect the $a$ priori definitions that we used to identify these types. Communities were generally defined based upon the appearance and composition of the canopy, or, in the case of old fields, by the absence of canopy and the presence of dense shrubs and groundflora. As canopy structure can have profound effects on lower vegetation strata, the differences that the data show throughout all vegetation strata are not unexpected, and they support our decision to stratify sampling based on community type.

\section{Understory Tree and Shrub Analysis (Objective 2)}

\section{Understory density}

As with the overstory, the understory density differences between vegetation communities reflects differences we expected when sampling was stratified by vegetation community. Old fields contained the highest density of understory stems and were dominated by the shrubs Rubus pensilvanicus, Rhus copallina, and Symphoricarpos orbiculatus. Additionally old fields were open and there was no competition from an overstory thus the shrub layer flourished in these communities. Cedar thickets were dominated by the shrub Symphoricarpos orbiculatus and the trees Fraxinus americana, Quercus stellata, Q. velutina, Rhamnus caroliniana, and Juniperus virginiana. Exposed oak forests frequently contained the shrubs Symphoricarpos orbiculatus, Vaccinium stamineum, and V. vacillans. All are low growing 
shrubs that can occur in dense clusters. The density of stems in old fields and cedar thickets may be sufficiently high to physically limit the use of these areas as either travel corridors or for foraging. This may be one factor causing the relatively low browse intensity observed within these communities compared to oak forests.

Variations in stem density between years are not likely due to deer browse. These variations are more likely due to sampling error and annual fluctuations in any number of factors, such as seed production, seed germination, vegetative reproduction, above ground shoot dieback and mortality. All of these can be extremely variable and may be tied to both life history traits and to climatic variables such as precipitation and temperature (Boerner and Brinkman 1996, Johnson et al. 2002). Nevertheless, the variability recorded over this two year study should indicate that, in order to detect change due to deer browse, future studies should look for longterm trends in stem density.

\section{Understory height}

We do not attribute differences in understory height between communities to the effects of deer browse. Rather, these differences more likely are the result of canopy structure and species composition within each community.

Understory heights may be lower in cedar thickets $(0.39 \mathrm{~m})$ due to the fact that cedar crowns create a dense canopy that limits seedling growth both by shading and by physical crowding. At higher overstory density levels there is more competition for growing space, water, nutrients, and light. This competition may result in frequent die-back and resprout of understory plants. Similar canopy effects may be hindering seedling growth in forested communities. By contrast, old fields, which have the tallest mean understory height $(0.74 \mathrm{~m})$, 
had virtually no canopy. Overstory competition for light and space poses fewer limitations in these communities. Also, stem densities in some old field plots were so high that deer may avoid these areas altogether, thereby limiting the effect of browse on mean stem height.

Regarding the relationship between understory height and species composition, exposed oak forests had frequent high densities of the low-growing shrubs, Vaccinium stamineum and $V$. vacillans. These species contributed to an overall reduction in mean understory height (Table 6). By contrast, old field plots frequently contained high abundances of the trees Diospyros virginiana and Sassafras albidum and the tall shrub Rhus copallina. These species in high abundance may have elevated mean height in old fields. Protected oak communities frequently contained Diospyros virginiana, Sassafras albidum, Cornus florida, Quercus velutina, and Fraxinus americana in the understory, but they also frequently contained the low growing shrubs Symphoricarpos orbiculatus and Rubus pensilvanicus. Given this mix of tall and low-growing woody species, it is not surprising that protected forests had a mean stem height between the two extremes of old fields and exposed forests. Species composition may have been less a determinant of mean understory height in cedar thickets, where trees species were among the most frequent and most dense of the species recorded. Here, canopy closure might be more important as a limit to seedling height.

\section{Understory species richness}

The lower species richness recorded in old fields (4.85, compared to $>9$ for all other communities) is unlikely due to the effects of deer browse. A more plausible explanation lies in the fact that, due to time limitations, we sampled in old fields an area equivalent to $1 / 4$ the area sampled in other communities. However, species richness in old fields may also be limited by non-deer related factors, such as the suppression of other plants by aggressive, densely growing 
species such as Rubus spp., Symphoricarpos orbiculatus, Festuca spp., and Rhus copallina. We do not attribute differences in understory species richness between years to the fact that plots were sampled during different periods each year, as understory stems are persistent and detection is not affected by sampling time.

\section{Understory density by height class}

Our analysis identified a trend in understory density in the cedar thickets and oak forest communities in which height class 2 (1-2 m) had a lower density than height class 3 (> $2 \mathrm{~m}$, Table 7). This contradicts a principle of decreasing density with increasing size (Oliver and Larson 1990). That height class 2 should be consistently less dense than height class 3 may indicate a potential browse effect. Class 2 represents stems that are continuously available for browse, as these stems are not hidden by the groundflora layer and they are within the maximum browse height. If future research indicates an increase in mean height class 2 density within exclosures and no change outside of exclosures, this would support the hypothesis that deer are reducing stem densities within this height class. On the other hand, density may be higher in height class 3 because it is an open ended height class, incorporating all stems above $2.1 \mathrm{~m}$ tall until they achieve a $\mathrm{DBH}>5.0 \mathrm{~cm}$. If this were the case, one would expect to see no future changes in the patterns observed in this study.

Height class density analysis also showed that the density in height class 1 was significantly different between 2002 and 2003 while the other height classes were not different. The smallest height class is the most variable class over time. Boerner and Brinkman (1996) found that the seedling layer was characterized by high mortality and short longevity, with $95 \%$ mortality within the first year after germination. Such a high turnover in this layer could explain the between-year differences identified in this study. Additionally sampling error in the smallest 
height class between 2002 and 2003 may account for some of the differences identified in the analysis.

Understory species richness by height class

Richness in height class 1 reflects the pattern seen when comparing overall richness among communities (Tables 4 and 8). Cedar thickets are most rich, followed by exposed oak forests, protected oak forests, and finally old fields, with only this latter community significantly different from the others (though this difference may be due to a diminished sample area in old fields). The fact that the values between height class 1 richness and total richness are so similar suggests that height class 1 is the primary determinant of overall richness.

Deer browse could be one factor causing height class richness values to diverge from expected patterns. As with density measures, one would expect to see diminished species richness as organism size increases (in this case, with larger height class). However, our data show lower richness in height class 2 than in height class 3 in all communities except old fields. This may be because height class 2 stems are readily available for browse, while most stems in height class 3 are beyond the maximum browse height. If this causal link is true, it would also explain why the expected pattern of diminishing richness with increasing size was found in old fields alone. Browse intensity was the lowest in these communities, so deer would have the least impact on the distribution of stems through the various size classes. Another potential reason richness differed between the height class 2 and 3 is that height class 3 is a broader class than class 2 . 


\section{Groundflora Analysis (Objective 3)}

\section{Groundflora species richness}

The high mean groundflora richness recorded in old fields (37.5) and cedar thickets (27.6) is likely due to the fact that these are dynamic, transitional communities. As such, these communities include species established during past land use practices (particularly non-native species such as tall fescue), species that established after the cessation of those practices (i.e. invasive species such as Rosa multiflora), and species that are becoming established that represent a more stable community (i.e. prairie grasses). By contrast, the lower richness found in forested communities may reflect their stability, rather than any effect of deer browse. Annual groundflora differences may also be due to seasonal variation. Unlike woody stems, detection of herbaceous vegetation is highly dependent upon when sampling occurs during the growing season. Inconsistent sampling times between years may cause species detected in one year to be missed during the next, or may lead to inconsistent estimates of richness. In 2002 plots were sampled in June, July, and August but in 2003 all plots were sampled in August.

\section{Groundflora percent cover}

The high mean percent cover in old fields (125.4\%) results from the fact that these communities are characterized by densely overlapping herbaceous and low, woody stems. By contrast forested communities and cedar thickets were characterized by their nearly closed or dense canopies, a factor that inhibits groundflora growth. Annual differences in percent cover are likely due to environmental effects such as drought, and not to any deer browsing activity. Annual groundflora differences may also be due to seasonal variation, in 2002 plots were sampled in June, July, and August but in 2003 all plots were sampled in August. 


\section{Browse Survey Analysis}

\section{Proportion of Twigs Browsed among Four Vegetation Communities (Objective 4)}

Overall comparison of proportion of twigs browsed between vegetation communities

The consistently higher proportion of browsed twigs in oak forests may indicate that these communities provide preferential browse habitat relative to other communities. In winter months, when browsing of woody twigs is most common, mature trees would provide winter cover and hard mast in the form of acorns and hickory nuts. These factors may attract deer to the area and increase browsing. Exposed oak forests would have the added attraction of receiving direct solar radiation during the day, which would make these areas warmer and may explain why exposed oak forests consistently had both the highest total number and the highest proportion of browsed twigs. By contrast, cedar thickets and old fields lack hard mast production. Additionally, old fields are extremely dense with stems (limiting deer mobility), and they lack a dense canopy that would provide winter thermal cover found in the other communities. These factors may explain why old fields consistently had both the lowest total number and lowest proportion of browsed twigs. LaGory et al. (1985) also found that old fields were browsed less intensely than forested communities.

Proportion of twigs browsed between height classes among four vegetation communities

One possible explanation of why the proportion of twigs browsed in height class 1 (0.055) was more than an order of magnitude greater than in height classes 2 and 3 combined (0.004) is that deer browse may have shortened twigs sufficiently to cause an alteration in the height class to which they were assigned. Many of the twigs recorded as browsed in height class 1 may have been tall enough to be counted in height class 2 prior to browsing by deer. The 
effect of browse would be to decrease overall twig density in the higher class (as we observed in cedar thickets and forested communities) and increase overall twig density and the proportion of twigs browsed in the smaller height class.

On the other hand, the differences in browse intensity between height classes may also reflect size-specific preferential browsing. The shoots in height class 1 may be more palatable to deer, either due to tenderness, the absence of pathogens, or to higher nutrient content. Regardless of why twigs in height class 1 are browsed more, the data suggest that if seedlings can be protected from browse until reaching a higher height class, they will be less susceptible to browsing. Annual differences in the proportion of twigs browsed are probably the result of annual fluctuations in overall stem density and sampling variability.

\section{Deer Browse of Oak and Hickory Compared to Other Species (Objective 5)}

Our data do not support the notion that deer are preferentially browsing oak and hickory seedlings. Using combined data from all communities, the proportion of browsed oak and hickory seedlings (0.039) was virtually the same as that for other species $(0.033)$, with wide confidence intervals for both species groups. No oaks or hickories were preferentially browsed in old fields. In cedar thickets, two oak species (Quercus stellata and Quercus velutina) were classified as preferentially browsed, while Quercus marilandica and Carya texana were classified as infrequently browsed. In exposed forests, the only preferentially browsed oak or hickory was Carya texana, which exceeded the minimum value by less than one percent. Within the same community, six other oak and hickory species were classified as proportionally browsed or infrequently browsed. In protected forests, post oak was the only one of four oaks and hickories to be classified as preferentially browsed. Of the four preferentially browsed oak and hickory species in all communities, only post oak in protected forests had a browse 
frequency that greatly exceeded the minimum value for that designation. Therefore, there is no consistent pattern of oaks and hickories being preferentially browsed

Mean browse frequency for all species may have been suppressed by the extremely high twig densities and low browse frequencies for species such as Juniperus virginiana and Ulmus alata. These two species accounted for nearly $50 \%$ of the twigs available for browse, but were consistently among the least frequently browsed species. This fact contradicts studies in which Juniperus virginiana and Ulmus alata elm were shown to be preferentially browsed species (LaGory et al 1995, Castleberry et al 1999). The low browse frequency for Juniperus virginiana and Ulmus alata may be one reason why Quercus stellata and Quercus velutina were classified as preferentially browsed in cedar thickets, even though the browse frequencies for these species were less than five percent. It may also explain why Carya texana was classified as preferentially browsed in exposed oak forests, despite having a less than eleven percent browse frequency.

\section{Exclosure Analysis}

\section{Understory Tree and Shrub Exclosure Analysis (Objective 6)}

\section{Understory stem density}

The difference in understory stem density between exclosed (20250 stems/ha) and unexclosed areas (14600 stems/ha) is likely an artifact of patchiness in understory density and of a small sample size. It is unlikely that these differences are the result of any browse effect. The exclosures were finished in March of 2003, and plots were re-sampled during the summer of 
2003. Therefore, prior to sampling during the second summer, the exclosures had been in place less than five months. The effects of exclosures are highly variable and can require at least a few years before effects are noticeable. Hough (1949) estimated that an exclosure needs to be in place for between five to ten years before an effect is noticed. Other research has shown that even after an area was exclosed for 15 years, there was very little difference between exclosed and unexclosed areas (Webb et al. 1956, Tierson et al. 1966).

It is also unlikely that differences in understory stem density recorded between exclosed and unexclosed areas are due to herbivory by species other than deer. Other mammals do influence understory recruitment, survival, and growth. Rabbits and deer have similar winter browsing preferences, and an over-population of either mammal can alter understory density (Hough 1949). Additionally, rodents are major predators on new seedlings (Walters and Auchmoody 1993). However, the plot-exclosure design used in this study provides adequate space for small mammals to reach the interior of exclosed areas, and should not hinder browsing by species other than deer.

\section{Understory height and richness}

No significant differences were found in the mean height of shrubs and saplings between exclosed and unexclosed areas. This is true within individual community types and across all community types. Significant differences in understory richness between exclosed and unexclosed areas could only be found in protected oak forests. These differences do not show up when comparing across all communities. As with density, the short time between exclosure construction and sampling make it unlikely that the minute differences observed in understory height and richness between exclosed and unexclosed areas could be attributable to the exclusion of deer browsing. 


\section{Groundflora Exclosure Analysis (Objective 7)}

\section{Groundflora species richness}

Exclosed areas had significantly higher species richness than unexclosed areas (9.8 more species per plot). The difference between exclosed and unexclosed areas may be due to differences in sampling time. Plots were sampled in June, July, and August in 2002 and only in August in 2003. The data analysis may be detecting seasonal changes in groundflora. Additionally differences in groundflora may be due to patchiness and annual fluctuations in groundflora richness rather than to an effect of deer browse. Moisture levels that fluctuate over the space of a few meters may be affecting richness values, particularly when moisture becomes a limiting agent (as during late-season drought). Given the small sample size and short duration of this study, the probability that these factors could cause data to be significantly different between treatments is high. However, it remains possible that exclosures have created conditions that would favor an increase in groundflora richness by reducing deer browse. Groundflora can respond more rapidly to exclosure treatments than can taller vegetation strata dominated by woody stems (Augustine and Frelich 1998, Frankland and Nelson 2003, Inouye et al. 1994). Long-term monitoring will yield data sufficient to determine if differences in richness between exclosed and unexclosed areas are due to browse or due to other factors.

\section{Groundflora cover}

No significant differences exist in vegetation percent cover between exclosed and unexclosed areas. The effects of browse on cover, if there are any, may be obscured by the physiological response of browsed plants and neighboring plants. Browsed plants may respond with vigorous new growth involving shoot elongation and branching. These would allow a 
browsed individual to quickly fill space it once held. Similarly, neighboring plants can rapidly occupy space vacated by a browsed stem, an effect more likely when browsing causes mortality of the browsed stem. One would expect to see changes in species composition with this latter effect, as preferentially browsed species would presumably be eliminated over time. Future sampling may provide more conclusive evidence that browsing is or is not affecting groundflora cover. 


\section{Management Implications}

This study was conducted in response to specific requests from resource managers at Pea Ridge National Military Park, who were concerned that deer browse might be adversely affecting plant communities by 1) actively changing existing communities, and 2) hindering restoration and preservation activities. This study was intended to establish baseline information regarding browse intensity and to establish plots for studying the long-term effect of deer-browseinhibiting exclosures on plant communities.

The short duration of this study provided only slight evidence to support the concerns that deer are having an adverse effect on plant communities within PERI. Specific areas of concern include: 1) the diminished density of stems in height class 2 relative to expected values, and 2) the higher browse intensity in oak forests compared to other communities. The former condition suggests that deer may be preventing some woody stems from reaching deer-safe size classes throughout the park. Furthermore, deer are major predators of acorns (Walters and Auchmoody 1993, Steiner 1995), which may diminish seedling germination rates. These two factors (browsing of existing stems and reduced germination rates due to acorn predation) could combine to limit recruitment of new cohorts into the overstory. This is most critical in oak forests, within which browse intensity was higher.

It is possible that future monitoring using the exclosures established in this study will provide evidence that browsing by deer is preventing woody stems currently in the understory and groundflora from reaching maturity. This is the most likely causal link between overstory change and deer browse that could be established with future research. With that in mind, the most important measure to study over time will be the survival of woody stems into maturity. 
This should be traceable through changes in the density of understory woody stems in the various height classes used in this study. Groundflora measures should continue to be included, as vegetation strata within a given community respond at different rates to environmental variables such as deer browse. Groundflora respond quickly to exclosures (Augustine and Frelich 1998, Frankland and Nelson 2003), while tree regeneration response is slower (Inouye et al. 1994). Also, the groundflora measurements used in this study include measurements of woody stems too small to be recorded in the understory measurements. Understanding the fate of these stems will be important in understanding the effect of browse on woody stem mortality.

Either a positive or a negative response in understory stem density after exclosure construction may be a sign of deer browsing. On one hand, browsing may directly lower stem density and seed predation can indirectly lower stem density. On the other hand, browsing tends to remove apical meristems, which can induce branching, basal sprouting, and vigorous new growth. This effect may elevate density measures.

Mean understory height and the distribution of stems over multiple height classes will continue to be critical measures because deer browsing can delay the establishment of new cohorts by decreasing growth rates, due to the clipping of seedlings' terminal leader (Jordan 1967). This effect of deer browsing can make it difficult for woody stems to reach the advanced regeneration stage (Marquis and Brenneman 1981) and to subsequently reach a size that protects it from deer browse. It is important to note that the effects of exclosures on understory height can be independent of the effects on density. Marquis and Grisez (1978) found that six years after exclosure construction, the density of tree regeneration was not affected, but regeneration height did increase. Inouye et al. (1994) found that deer did not effect the establishment of trees in an old field but deer did have a significant effect on tree height. 
Of particular concern should be any changes relating to desirable plants (such as potential canopy trees in areas being managed for forest communities) or undesirable plants (such as invasive exotics). Within a commercial forest management context, deer browsing has been shown to reduce the density of desired species (Marquis 1975, Heinen and Sharik 1990). Other studies have shown that deer browse can increase the density of preferred species in the smallest height classes, but these individuals do not grow to the next size class. Browsing suppresses growth by clipping the terminal leader once it grows above surrounding vegetation (Tierson et al. 1966). Other work has shown that deer browsing can reduce the density of desirable species while increasing the density of undesirable species (Marquis 1981).

Some management activities may have similar effects to deer browse on the composition and structure of plant communities. Specifically, prescribed burning can affect survival of woody stems, particularly those within the browsing range of deer. Short-term changes in woody stems associated with burning may include a substantial reduction (if plants are killed) or increase (if only above ground shoots are killed, but the live roots remain) in stem density. Prescribed burning may redistribute stems between size classes and may differentially affect species composition. Prescribed fire is applied to most areas of PERI. It is a standard vegetation management practice at PERI, and researchers should pay particular attention to burned areas in order to separate the effects of prescribed fire from deer browse effects.

Specific management recommendations include the following:

1) Continue sampling the browse survey plots at five year intervals. Annual sampling would be ideal, but the cost for annual sampling will be significant. Dramatic changes in vegetation structure and composition can be identified with data collected in 5 year intervals but 
subtle changes will take longer to detect. Continued sampling of the browse survey plots will provide park wide data on the condition of the understory and groundflora layers.

2) Resample paired exclosed and unexclosed plots at five year intervals. Only long term data will accurately reflect the effect of deer exclusion on plant communities. Particular attention should be paid to changes in understory stem density (overall and within each height class), especially in desirable species, such as oaks and hickories, and in undesirable species, both native and invasive exotics. Annual sampling of the exclosed and unexclosed plots would be ideal but it is cost prohibitive. Dramatic changes in vegetation structure and composition can be quickly identified with data collected in 5 year intervals but subtle changes will take longer to detect 


\section{References}

Adams, A.S. and L.K. Rieske. 2001. Herbivory and fire influence white oak (Quercus alba L.) seedling vigor. Forest Science 47(3): 331-337.

Anderson, R.C. and O.E. Loucks. 1979. White-tail deer (Odocoileus virginianus) influence on structure and composition of Tsuga canadensis forests. Journal of Applied Ecology 16: 855-861.

Augustine, D.J. and L.E. Frelich. 1998. Effects of white-tailed deer on populations of an understory forb in fragmented deciduous forests. Conservation Biology 12(5): 995-1004.

Augustine, D.J. and P.A. Jordan. 1998. Predictors of white-tailed deer grazing intensity in fragmented deciduous forests. Journal of Wildlife Management 62(3): 1076-1085.

Beals, E., G. Cottam and R. Vogl. 1960. Influence of deer on vegetation of the Apostle Islands, Wisconsin. Journal of Wildlife Management 24: 66-80.

Boerner, R.E. and J.A. Brinkman. 1996. Ten years of tree seedling establishment and mortality in an Ohio deciduous forest complex. Bulletin of the Torrey Botanical Club 123(4): 309317.

Bonate, P.L. 2000. Analysis of pretest-posttest designs. Chapman \& Hall/CRC, Boca Raton, FL.

Bowersox, T.W., G.L. Storm, and W.M. Tzilkowski. 1995. Canopy openings and white-tailed deer influence the understory vegetation in mixed oak woodlots. In: Proceedings of the $10^{\text {th }}$ Central Hardwood Forest Conference. Eds: K.W. Gottschalk and S.L.C. Fosbroke. March 5-8. Morgantown, WV. General Technical Report NE-197. Pp. 206-213. USDA Forest Service. Northeastern Forest Experiment Station

Burnham, K.P. and D.R. Anderson. 2002. Model selection and multimodel inference: A practical information-theoretic approach, $2^{\text {nd }}$ edition. Springer-Verlad, New York, NY.

Castleberry, S.B., W.M. Ford, K.V. Miller, and W.P. Smith. 1999. White-tailed deer browse preferences in a southern bottomland hardwood forest. Southern Journal of Applied Forestry 23(2): 78-82.

Frankland, R. and T. Nelson. 2003. Impacts of white-tailed deer on spring wildflowers in Illinois, USA. Natural Areas Journal 23(4): 341-348.

Frelich, L.E. and C.G. Lorimer. 1985. Current and predicted long-term effects on deer browsing in hemlock forests in Michigan, USA. Biological Conservation 34: 99-120.

Heinen, J.T. and T.L. Sharik. 1990. The influence of mammalian browsing on tree growth and mortality in the Pigeon River State Forest, Michigan. American Midland Naturalist 123(1): 202-206.

Hough, A.F. 1949. Deer and rabbit browsing and available winter forage in Allegheny hardwood forests. Journal of Wildlife Management 13(1): 135-141.

Inouye, R.S., T.D. Allison and N.C. Johnson. 1994. Old field succession on a Minnesota sand plain: Effects of deer and other factors on invasion by trees. Bulletin of the Torrey Botanical Club 121(3): 266-276. 
Johnson, P.S., S.R. Shifley and R. Rogers. 2002. The ecology and silviculture of oaks. CABI Publishing. New York, NY. 503pp.

Johnson, S.A., P.E. Hale, W.M. Ford, J.M. Wentworth, J.R. French, O.F. Anderson, and G.B. Pullen. 1995. White-tailed deer foraging in relation to successional stage, overstory type and management of Southern Appalachian Forests. American Midland Naturalist 133: 18-35.

Jordan, J.S. 1967. Deer browsing in northern hardwoods after clearcutting: effect on height, density, and stocking of regeneration of commercial species. USDA Forest Service. Research Paper NE-57. Northeastern Forest Experiment Station. 15pp.

LaGory, M.K., K.E. LaGory and D.H. Taylor. 1985. Winter browse availability and use by white-tailed deer in southeastern Indiana. Journal of Wildlife Management 49(1): 120124.

Littell, R.C., G.A. Milliken, W.W. Stroup and R.D. Wolfinger. 1996. SAS System for mixed models. SAS Institute Inc., Cary, NC. 633pp.

Manly, B., L.L. McDonald, D.L. Thomas, T.L. McDonald, and W.P. Erickson. 2002. Resource selection by animals: Statistical design and analysis of field studies, $2^{\text {nd }}$ edition. Kluwer Academic Publishers, Boston, MA 221 pp.

Marquis, D.A. 1975. The impact of deer browsing on Allegheny hardwood regeneration. USDA Forest Service. Research Paper NE-308. Northeast Forest Experiment Station. 8pp.

Marquis, D.A. 1981. Effect of deer browsing on timber production in Allegheny hardwood forest of Northwestern Pennsylvania. USDA Forest Service. Research Paper NE-475. 10p.

Marquis, D.A. and R. Brenneman. 1981. The impact of deer on forest vegetation in Pennsylvania. USDA Forest Service. General Technical Report NE-65. Northeast Forest Experiment Station. 7pp.

Marquis, D.A. and T.J. Grisez. 1978. The effect of deer exclosures on the recovery of vegetation in failed clearcuts on the Allegheny plateau. USDA Forest Service. Research Note NE270. Northeast Forest Experiment Station. 5pp.

Miller, S.G., Bratton, S.P. and Hadidian, J. 1992. Impacts of white-tailed deer on endangered and threatened vascular plants. Natural Areas Journal 12(2): 67-74.

Milliken, G.A. and D.E. Johnson. 1992. Analysis of messy data, Volume I: Designed Experiments. Chapman and Hall. New York, NY. 473pp.

Moore, D.M. 1999. Trees of Arkansas, $5^{\text {th }}$ revised edition. Arkansas Forestry Commission. Little Rock, Ark. 142pp.

Oliver, C.D. and B.C. Larson. 1990. Forest Stand Dynamics. McGraw-Hill, Inc, New York, NY.

Pedersen, B.S. and A.M. Wallis. 2004. Effects of white-tailed deer herbivory on forest gap dynamics in a wildlife preserve, Pennsylvania, USA. Natural Areas Journal 24(2): 82-94.

Ritchie, M. and D. Tilman. 1995. Responses of legumes to herbivores and nutrients during succession on a nitrogen-poor soil. Ecology 76(8): 2648-2655.

Ritchie, M.E., D. Tilman, and J.M.H. Knops. 1998. Herbivore effects on plant and nitrogen dynamics in oak savanna. Ecology 79(1): 165-177. 
Rodewald, A.D. 2003. Decline of oak forests and implications for forest wildlife conservation. Natural Areas Journal 23(4): 368-371.

Rooney, T.P. and D.M. Waller. 2003. Direct and indirect effects of white-tailed deer in forest ecosystems. Forest Ecology and Management 181: 165-176.

Russell, F.L., D.B. Zippin, and N.L. Fowler. 2001. Effects of white-tailed deer (Odocoileus virginianus) on plants, plant populations and communities: A review. The American Midland Naturalist 146(1): 1-26.

SAS 1999. SAS OnlineDoc ${ }^{\circledR}$, Version 8. SAS Institute Inc., Cary, NC.

Snedecor, G.W. and W.G. Cochran. 1989. Statistical Methods, $8^{\text {th }}$ Edition. Iowa State University Press, Ames. 503p.

Steiner, K.C. 1995. Autumn predation of northern red oak seed crops. In: Proceedings of the 10th Central Hardwood Forest Conference. Eds: Gottschalk, K.W. and Fosbroke, S.L.C. March 5-8, Morgantown, WV. USDA Forest Service. Northeastern Forest Experiment Station. General Technical Report NE-197. Pp. 489-494

Strole, T.A. and R.C. Anderson. 1992. White-tailed deer browsing: Species preferences and implications for central Illinois forests. Natural Areas Journal 12(3): 139-144.

Tierson, W.C., E.F. Patric and D.F. Behrend. 1966. Influence of white-tailed deer on the logged northern hardwood forest. Journal of Forestry 64: 801-805.

Verbeke, G. and G. Molenberghs. 1997. Linear mixed models in practice: A SAS-oriented approach. Springer-Verlag, New York, NY. 306pp.

Walters, R.S. and L.R. Auchmoody. 1993. Factors limiting northern red oak reproduction in Pennsylvania. In: Proceedings of the $9^{\text {th }}$ Central Hardwoods Conference. Eds: A.R. Gillespie, G.R. Parker, P.E. Pope and G. Rink. March 8-10, West Lafayette, IN. General Technical Report NC-161. USDA Forest Service. North Central Forest Experiment Station. P. 271-280.

Webb, W.L., R.T. King and E.F. Patric. 1956. Effect of white-tailed deer on a mature northern hardwood forest. Journal of Forestry 54: 391-398. 